BNL-114463-2017-JA

\title{
Correlations between Transition Metal Chemistry, Local Structure and Global Structure in Li2Ru0.5Mn0.5O3 Investigated in a Wide Voltage Window
}

\author{
Y. Lyu, E. Hu \\ Submitted to Chemistry of Materials
}

October 2017

Chemistry Department

Brookhaven National Laboratory

\section{U.S. Department of Energy \\ USDOE Office of Energy Efficiency and Renewable Energy (EERE)}




\section{DISCLAIMER}

This report was prepared as an account of work sponsored by an agency of the United States Government. Neither the United States Government nor any agency thereof, nor any of their employees, nor any of their contractors, subcontractors, or their employees, makes any warranty, express or implied, or assumes any legal liability or responsibility for the accuracy, completeness, or any third party's use or the results of such use of any information, apparatus, product, or process disclosed, or represents that its use would not infringe privately owned rights. Reference herein to any specific commercial product, process, or service by trade name, trademark, manufacturer, or otherwise, does not necessarily constitute or imply its endorsement, recommendation, or favoring by the United States Government or any agency thereof or its contractors or subcontractors. The views and opinions of authors expressed herein do not necessarily state or reflect those of the United States Government or any agency thereof. 


\title{
Correlations between Transition Metal Chemistry, Local Structure and Global Structure in $\mathrm{Li}_{2} \mathrm{Ru}_{0.5} \mathrm{Mn}_{0.5} \mathrm{O}_{3}$ Investigated in a Wide Volt- age Window
}

\author{
Yingchun $\mathrm{Lyu}^{\dagger, \S,}, \stackrel{\perp}{ }$, Enyuan $\mathrm{Hu}^{\ddagger}{ }^{\ddagger}$, , Dongdong Xiao ${ }^{\dagger}$, Yi Wang ${ }^{\dagger}$, Xiqian $\mathrm{Yu}^{*}{ }^{*}$, , Guiliang $\mathrm{Xu}^{\#}$, Steven N. \\ Ehrlich ${ }^{\$}$, Khalil Amine ${ }^{\#}$, Lin Gu* ${ }^{*}, \dagger, \|$, Xiao-Qing Yang ${ }^{\ddagger}$ and Hong Li ${ }^{*}, \dagger$ \\ $\dagger$ Beijing National Laboratory for Condensed Matter Physics, Institute of Physics, Chinese Academy of Sciences, Beijing \\ 100190, China \\ $¥$ Chemistry Division, Brookhaven National Laboratory, Upton, NY 11973, USA \\ \# Chemical Sciences and Engineering Division, Argonne National Laboratory, Argonne, IL 60439, USA \\ $\S$ Materials Genome Institute, Shanghai University, Shanghai 200444, China \\ $\|_{\text {Collaborative Innovation Center of Quantum Matter, Beijing 100190, China }}$ \\ \$ NSLS-II, Brookhaven National Laboratory, Upton, NY 11973, USA
}

Keywords: Lithium-ion batteries, cathode, lithium rich layered oxides

\begin{abstract}
Li}_{2} \mathrm{Ru}_{0.5} \mathrm{Mn}_{0.5} \mathrm{O}_{3}$, a high capacity lithium rich layered cathode material for lithium-ion batteries, was subject to comprehensive diagnostic studies including in situ/ex situ X-ray diffraction (XRD), X-ray absorption spectroscopy (XAS), pair distribution function (PDF) and high resolution scanning transmission electron microscopy (STEM) analysis, to understand the correlations between transition metal chemistry, structure and lithium storage electrochemical behavior. Ru-Ru dimers have been identified in the as-prepared sample and found to be preserved upon prolonged cycling. Presence of these dimers, which are likely caused by the delocalized nature of $4 \mathrm{~d}$ electrons, is found to favor the stabilization of the structure in a layered phase. The in situ XAS results confirm the participation of oxygen redox into the charge compensation at high charge voltage, and the great flexibility of the covalent bond between $\mathrm{Ru}$ and $\mathrm{O}$ may provide great reversibility of the global structure despite of the significant local distortion around $\mathrm{Ru}$. In contrast, the local distortion around Mn occurs at low discharge voltage and is accompanied by a "layered to 1T" phase transformation, which is found to be detrimental to the cycle performances. It is clear that the changes of local structure around individual transition metal cations respond separately and differently to lithium intercalation/deintercalation. Cations with the capability to tolerate the lattice distortion will benefit for maintaining the integrality of the crystal structure and therefore is able to enhance the longterm cycling performance of the electrode materials.
\end{abstract}

\section{- INTRODUCTION}

Lithium rich layered oxides have attracted a great deal of interests as cathode materials for high energy density lithium ion batteries. ${ }^{1-}$

15 These materials can be described in average structure of $\alpha$ $\mathrm{NaFeO}_{2}(R \overline{3} m)$ where excess lithium ions exist in transition metal layers, exhibiting high reversible lithium storage capacity of 250$300 \mathrm{mAh} \mathrm{g}^{-1}$, twice that of commercialized $\mathrm{LiCoO}_{2}$. Among them, lithium rich manganese based layered oxides (LMLO) are intensively explored. ${ }^{1-11}$ Consensus has been reached that oxygen release ${ }^{5-6}$ and redox reaction on oxygen anions ${ }^{13,16-20}$ partially contributes to the large irreversible capacity observed on first charge and abnormally high reversible capacity on the subsequent cycles. The anionic redox process also triggers migration of transition metal ions, creation of oxygen vacancies and release of oxygen gas, resulting in capacity decay and voltage fade which are major problems that need to be solved for practical applications. ${ }^{1-3,21-23}$ Attempts have been made to suppress or avoid evolution of oxygen by introducing other cations into LMLO, in particular 3d or 4d transition metals (e.g. $\mathrm{Cr}, \mathrm{Mo}, \mathrm{Nb}, \mathrm{Ru}$ ) having the capability to realize multiple electron transfer. ${ }^{24-33}$ The different chemical nature of these elements also affect the bonding nature (e.g. covalency) with oxygen and thus affect the anionic redox process as well as the associated structural degredation. ${ }^{12-13,19,34}$ Therefore, it will be interesting to investigate lithium rich layered oxides with variant combination of transition metal cations so as to understand the interplay between chemical nature of transition metal elements and the lithium storage behavior.

In addition, the lithium rich layered materials present complex short-range structures, as some are described in a composite form with integration of trigonal $\mathrm{LiMO}_{2}$ phase $(R \overline{3} \mathrm{~m})$ and monoclinic $\mathrm{Li}_{2} \mathrm{MO}_{3}$ phase $(C 2 / m)$, while others are claimed to preserve a single solid-solution structure with long-range ordering. ${ }^{9-10,} 35-39$ These differences may arise from not only the different synthetic protocols but also the physical and chemical nature (size, charge etc.) of different elements constituting these materials. It has been argued that different short-range structures will result in differences in overall de/intercalation kinetics for lithium rich oxides. ${ }^{40}$ Moreover, the changes of local structure upon electrochemical cycling are closely related to the overall crystal structural stability associated with cycle performances. Therefore, it will be of great importance to investigate the short-range structure in a variety of lithium rich oxide compounds composed of different transition metal cations, as well as the structural evolution along with lithium insertion and extraction.

In this manuscript, the lithium rich layered cathode $\mathrm{Li}_{2} \mathrm{Ru}_{0.5} \mathrm{Mn}_{0.5} \mathrm{O}_{3}$, with the combination of $3 \mathrm{~d}$ and $4 \mathrm{~d}$ transition metal cations in transition metal layer, is being focused on. The $4 \mathrm{~d}$ $\mathrm{Ru}$ based lithium rich oxides have attracted intensive interests recently, because $\mathrm{Ru}$ is able to realize multiple electron transfer and thus has the capability to achieve high lithium storage capacity. Numerous research work indicates that $\mathrm{Ru}$ based lithium rich oxides 
show fairly good capacity retention (cycle performances) as well as good structural stability (suppress voltage fade)..$^{12,15,21,41}$ However, the detailed mechanisms need further in-depth exploration. There are two major reasons to choose the specific composition of $\mathrm{Li}_{2} \mathrm{Ru}_{0.5} \mathrm{Mn}_{0.5} \mathrm{O}_{3}$ : (1) From a structural point of view, the similar crystal structure of $\mathrm{Li}_{2} \mathrm{RuO}_{3}$ to that of $\mathrm{Li}_{2} \mathrm{MnO}_{3}$ enables their integration into a solid solution phase at atomic scale, ${ }^{15,28}$ and thus might potentially simplify the structural analysis and make it an ideal model material to demonstrate. (2) $\mathrm{Li}_{2} \mathrm{Ru}_{0.5} \mathrm{Mn}_{0.5} \mathrm{O}_{3}$ exhibits the best electrochemical performances among the series of $\mathrm{Li}_{2} \mathrm{Ru}_{\mathrm{x}} \mathrm{Mn}_{1-\mathrm{x}} \mathrm{O}_{3}$ compounds $(\mathrm{x}=0,0.2,0.4,0.5,0.6,0.8,1)$ as reported by Sathiya and coworkers. ${ }^{15}$

The lithium storage behavior in $\mathrm{Li}_{2} \mathrm{Ru}_{0.5} \mathrm{Mn}_{0.5} \mathrm{O}_{3}$ will be discussed in detail in the present work and the discussion is divided into two parts. Firstly, the structural evolution of $\mathrm{Li}_{2} \mathrm{Ru}_{0.5} \mathrm{Mn}_{0.5} \mathrm{O}_{3}$ on multilength scales over the first charge-discharge process are studied by using a combination of characterization techniques, such as X-ray diffraction (XRD), X-ray absorption spectroscopy (XAS), pair distribution function (PDF) and scanning transmission electron microscopy (STEM). On the basis of these experimental observations, the origins of the highly reversible lithium storage capacity for $\mathrm{Li}_{2} \mathrm{Ru}_{0.5} \mathrm{Mn}_{0.5} \mathrm{O}_{3}$ and the factors that affect its cycle stability in the wide range of lithium extraction and insertion are discussed in the second half of the manuscript. Comparisons between $\mathrm{Li}_{2} \mathrm{Ru} 0.5 \mathrm{Mn}_{0.5} \mathrm{O}_{3}$ and lithium rich oxide composed of other transition metal cations are made, to highlight the uniqueness of the chemical nature of $\mathrm{Ru}$ to the different electrochemical behaviors.

\section{- RESULTS}

Structure of pristine $\mathrm{Li}_{2} \mathrm{Ru}_{0.5} \mathrm{Mn}_{0.5} \mathrm{O}_{3}$. The average crystal structure of $\mathrm{Li}_{2} \mathrm{Ru}_{0.5} \mathrm{Mn}_{0.5} \mathrm{O}_{3}$ was characterized by XRD with the result shown in Figure 1. The overall pattern indicates a well layered structure (e.g. the splitting of two peaks (108) and (110) between 63 and $65^{\circ}$ ). In addition to the peaks belonging to conventional layered structure, there are superlattice peaks between 20 and $35^{\circ}$ that arise from lithium/transition metal ordering. Such ordering reduces the symmetry of the crystal structure from original $R \overline{3} m$ to $C 2 / m$. A closer look at these superlattice peaks indicates that they are asymmetric, broadened, and different from those observed in the well crystallized $\mathrm{Li}_{2} \mathrm{MnO}_{3}$ which also has the $C 2 / m$ symmetry. Such differences have previously been attributed to stacking faults present in the material. ${ }^{42-43}$ In order to obtain more detailed information of the crystal structure, Rietveld refinement ${ }^{44}$ was carried out with TOPAS software using a model structure with $C 2 / \mathrm{m}$ symmetry. In this structure, there are two kinds of stacking planes: the lithium/transition metal plane where lithium occupies the $2 b$ site and transition metal occupies $4 \mathrm{~g}$ site and the lithium only plane where lithium occupies the $2 \mathrm{c}$ and $4 \mathrm{~h}$ sites. The detailed refinement results are shown in Table 1. As can be seen from the table, intraplanar cation mixing (between $2 \mathrm{~b}$ and $4 \mathrm{~g}$ sites within the lithium/transition metal plane) instead of interplanar cation mixing (between lithium/transition metal plane and lithium only plane) can well reproduce the XRD pattern. This agrees well with previous synchrotron XRD and neutron powder diffraction results of similar systems. ${ }^{15}$

However, it has been demonstrated by Miura and Kimber et al. that for pure $\mathrm{Li}_{2} \mathrm{RuO}_{3}$ the structure should be described by the $P 2_{1} / \mathrm{m}$ space group instead of the $C 2 / m$ space group used for $\mathrm{Li}_{2} \mathrm{MnO}_{3}$, due to the prevalence of $\mathrm{Ru}-\mathrm{Ru}$ dimers caused by metal-metal bonding. ${ }^{45-46} \mathrm{In} \mathrm{Li}_{2} \mathrm{Ru}_{0.5} \mathrm{Mnn}_{0.5} \mathrm{O}_{3}$, it is very likely that $\mathrm{Ru}-\mathrm{Ru}$ dimers still exist but the confirmation of its existence is challenging. A good fitting of the XRD pattern using the $C 2 / m$ space group does not rule out the possibility of such existence because $\mathrm{Ru}-\mathrm{Ru}$ dimers may distribute randomly and the whole symmetry is not lowered. To address this issue, pair distribution function (PDF) analysis, which provides both short-range and long-range structural information, was carried out and the results are shown in Figure 2. The peaks in PDF correspond to various atom-atom distances in the structure. Clearly, even though the $C 2 / \mathrm{m}$ space group can well describe the long-range (3.3-20 $\AA$ ) structure, it fails to describe the short-range structure $(1.7-3.3 \AA)$. The peak at around $2.5 \AA$ can only be fitted well using the $P 2_{1} / \mathrm{m}$ space group. Therefore, it is unambiguously shown that $\mathrm{Ru}-\mathrm{Ru}$ dimers still exist in $\mathrm{Li}_{2} \mathrm{Ru}_{0.5} \mathrm{Mn}_{0.5} \mathrm{O}_{3}$.

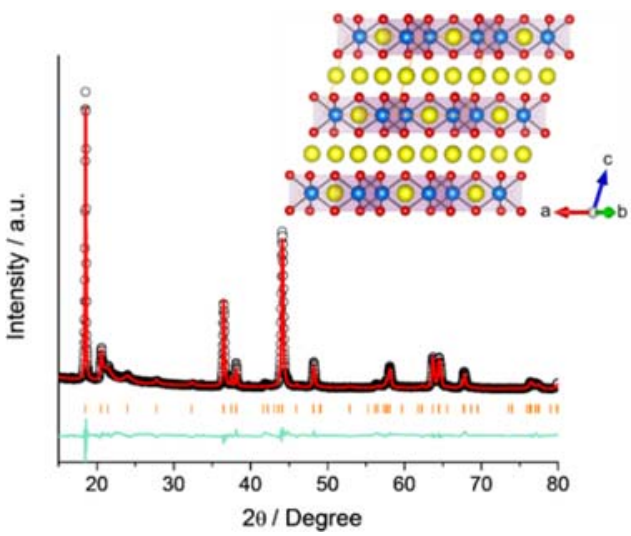

Figure 1. Rietveld refinement on the XRD data of the pristine $\mathrm{Li}_{2} \mathrm{Ru}_{0.5} \mathrm{Mn}_{0.5} \mathrm{O}_{3}$. The black circles and red lines correspond to the observed and calculated intensities respectively. The differences between the observed and calculated patterns (cyan line) and the referenced peak positions of $\mathrm{Li}_{2} \mathrm{Ru}_{0.5} \mathrm{Mn}_{0.5} \mathrm{O}_{3}$ corresponding to space group $\mathrm{C} 2 / \mathrm{m}$ are also shown. The inset shows the structure of the pristine $\mathrm{Li}_{2} \mathrm{Ru}_{0.5} \mathrm{Mn}_{0.5} \mathrm{O}_{3}$ material with the $\mathrm{O} 3$ stacking. Lithium atoms are yellow, transition metal are blue ( $\mathrm{Mn}$ and $\mathrm{Ru}$ ) and oxygen atoms are red.
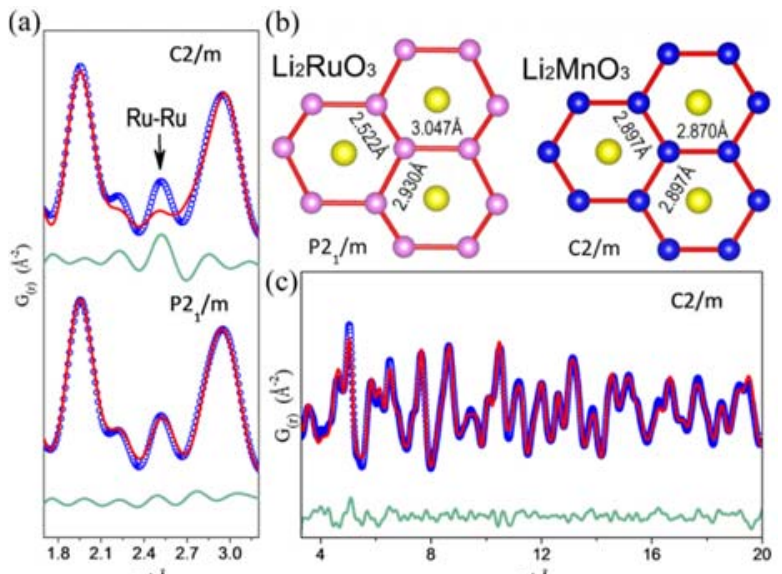

Figure 2. (a) Results of fitting the short-range (1.7-3.3 $\AA$ ) PDF data using $C 2 / m$ and $P 21 / m$ space group (blue circles: experimental data; red line: calculated intensities; dark cyan line: the difference). The arrow indicates that the short Ru-Ru bond can only be described well by the $P 21 / m$ space group. (b) The honeycomb clusters in $P 2_{1} / m$ and $C 2 / m$ space group. Lithium atoms are yellow, transition metal are magenta $(\mathrm{Ru})$ or blue $(\mathrm{Mn})$ and oxygen atoms are red. (c) Results of fitting the long range $(3.3<\mathrm{r}<20 \AA)$ PDF using model with $C 2 / m$ space group. 
Table 1. Results of the Rietveld refinement in $C 2 / m$ space group.

\begin{tabular}{cccccc}
\hline & Space group C2/m & \multicolumn{4}{c}{ Bragg R-factor= 5.4 } \\
\hline \multicolumn{1}{c}{$\mathrm{a}=4.994(1) \AA, \mathrm{b}=8.6626(9) \AA, \mathrm{c}=5.0743(8) \AA$ and $\beta=109.11(1)$} \\
\hline Atom & Wyckoff site & $\mathrm{X}$ & $\mathrm{Y}$ & $\mathrm{Z}$ & $0.814(7)$ \\
\hline Li1 & $2 \mathrm{~b}$ & 0 & 0.5 & 0 & $0.186(7)$ \\
TM on Li1 & & & & 0.5 & 1 \\
Li2 & $2 \mathrm{c}$ & 0 & 0 & 0.5 & $0.907(4)$ \\
Li3 & $4 \mathrm{~h}$ & 0 & $0.286(5)$ & 0 & $0.093(4)$ \\
TM on TM & $4 \mathrm{~g}$ & 0 & $0.1649(4)$ & & 1 \\
Li on TM & & & & $0.216(2)$ & 1 \\
O1 & $4 \mathrm{i}$ & $0.187(3)$ & 0 & $0.235(2)$ & 1 \\
O2 & $8 \mathrm{j}$ & $0.258(3)$ & $0.3081(9)$ & & \\
\hline
\end{tabular}

To further understand the local structure of the pristine material, HAADF-STEM was employed to obtain a direct vision of the atomic structure. The STEM image of pristine $\mathrm{Li}_{2} \mathrm{Ru}_{0.5} \mathrm{Mn}_{0.5} \mathrm{O}_{3}$ recorded along the [100] direction is shown in Figure 3. Since the image intensity of each atomic column reflects the average atomic number of each atomic column (approximately $\mathrm{Z}^{1.7}$ ), ${ }^{47}$ the bright dots in Figure 3a result from the heavy atomic columns ( $\mathrm{Ru}$ and $\mathrm{Mn})$ in $\mathrm{Li}_{2} \mathrm{Ru}_{0.5} \mathrm{Mn}_{0.5} \mathrm{O}_{3}$, while light atoms (O and $\mathrm{Li}$ ) are nearly invisible in the image. It can be seen that there are no bright dots (representing $\mathrm{Ru}$ and $\mathrm{Mn}$ columns) in lithium layers, which is consistent with the Rietveld refinement results that there is no cation mixing between the lithium only plane and the lithium/transition metal plane. In the lithium/transition metal plane, most areas mainly have a pattern with a pair of two bright dots followed by one dark dot, indicating a regular intraplanar arrangement of " $-\mathrm{Li}-$ TM-TM-Li-" $(\mathrm{TM}=$ transition metal) in the lithium/transition metal plane as often seen in $\mathrm{Li}_{2} \mathrm{MnO}_{3}{ }^{48}$ In addition, the dark column still exhibits some intensities, indicating the existence of transition metal ions in lithium column. These results agree well with the conclusion of intraplanar cation mixing determined by XRD. However, the lithium/transition metal plane appears a bit corrugated, which cannot be described by $\mathrm{Li}_{2} \mathrm{MnO}_{3}$ with $C 2 / m$ space group (Mn, 4g site: $0, \mathrm{y}, 0$ ) but perfectly match $\mathrm{Li}_{2} \mathrm{RuO}_{3}$ with $P 2_{1} / m$ space group (Ru, 4f site: $x, y, z)$ as shown in Figure $3 b$. Therefore, it further confirms the existence of $\mathrm{Ru}-\mathrm{Ru}$ dimers in $\mathrm{Li}_{2} \mathrm{Ru}_{0.5} \mathrm{Mn}_{0.5} \mathrm{O}_{3}$.

(a)

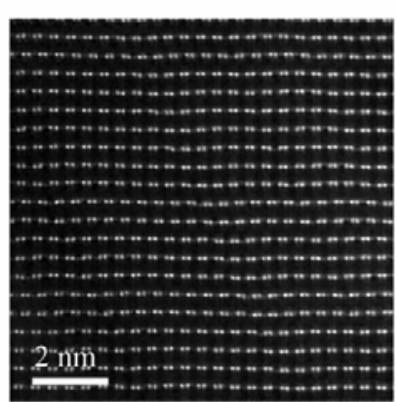

(b) $\mathrm{Li}_{2} \mathrm{MnO}_{3}(\mathrm{C} 2 / \mathrm{m})$

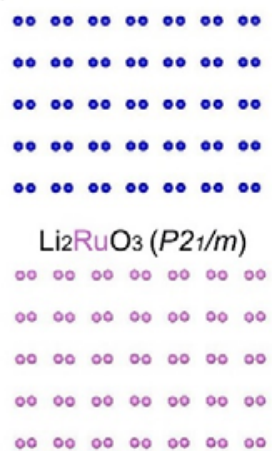

Figure 3. (a) The HAADF-STEM image of pristine $\mathrm{Li}_{2} \mathrm{Ru}_{0.5} \mathrm{Mn}_{0.5} \mathrm{O}_{3}$ along [100] zone axis. (b) The structures of
$\mathrm{Li}_{2} \mathrm{MnO}_{3}$ (space group: $C 2 / m$ ) and $\mathrm{Li}_{2} \mathrm{RuO}_{3}$ (space group: $\mathrm{P}_{1} / m^{45}$ ) respectively. Only transition metal ions are presented (Mn atom in blue and $\mathrm{Ru}$ atom in magenta). The lithium/transition metal plane become corrugated instead of flat in the presence of Ru-Ru dimers in $\mathrm{Li}_{2} \mathrm{RuO}_{3}$.

Electrochemical behaviors of $\mathrm{Li}_{2} \mathrm{Ru}_{0.5} \mathrm{Mn}_{0.5} \mathrm{O}_{3}$. To evaluate the structure stability of $\mathrm{Li}_{2} \mathrm{Ru}_{0.5} \mathrm{Mn}_{0.5} \mathrm{O}_{3}$ in a wide range of lithium intercalation/deintercalation, the $\mathrm{Li}_{2} \mathrm{Ru}_{0.5} \mathrm{Mn}_{0.5} \mathrm{O}_{3} / \mathrm{Li}$ half cells were assembled and cycled in the voltage range between 1 and $4.6 \mathrm{~V}$ at a rate of $0.1 \mathrm{C}$. The voltage profile of the $\mathrm{Li}_{2} \mathrm{Ru}_{0.5} \mathrm{Mn}_{0.5} \mathrm{O}_{3}$ sample shown in Figure 4a looks similar to that of LMLO composites. ${ }^{4-5}$, ${ }^{15}$ The first charge curve displays a first plateau located near $3.6 \mathrm{~V}$ (stage I) followed by a second plateau at $4.3 \mathrm{~V}$ (stage II). 1.79 mole lithium ions are estimated to be extracted from $\mathrm{Li}_{2} \mathrm{Ru}_{0.5} \mathrm{Mn}_{0.5} \mathrm{O}_{3}$ on first charge, reaching a chemical composition of $\mathrm{Li}_{0.21} \mathrm{Ru}_{0.5} \mathrm{Mn}_{0.5} \mathrm{O}_{3}$ at the end of the charge (corresponding to a charge capacity of 342 $\mathrm{mAh} \mathrm{g}^{-1}$ ). The following discharge profile is different as it shows two distinct slopes above and below $2 \mathrm{~V}$ respectively. A discharge capacity of $231 \mathrm{mAh} \mathrm{g}^{-1}$ is achieved on the first slope (stage III), similar to that observed in earlier reports. ${ }^{12,}{ }^{28}$ Further discharge causes an abrupt voltage drop followed by a voltage slope located at around $1.2 \mathrm{~V}$. A remarkably high discharge capacity of $402 \mathrm{mAh}$ $\mathrm{g}^{-1}$ is obtained for the entire discharge process. The charge-discharge profiles for subsequent cycles look the same. Hysteresis behavior are observed for each charge-discharge cycle and the charge-discharge profile looks asymmetric, that is the voltage profile displays a longer low voltage slope for discharge than that for the corresponding charge process. This phenomenon has also been observed in other layered cathode materials, such as $\mathrm{LiNi} 0.5 \mathrm{Mn}_{0.5} \mathrm{O}_{2}$, $\mathrm{Li}_{2} \mathrm{Ru}_{0.9} \mathrm{Zr}_{0.1} \mathrm{O}_{3}$ and $\mathrm{Li}_{1.2} \mathrm{Cr}_{0.4} \mathrm{Mn}_{0.4} \mathrm{O}_{2}$, cycled in a wide voltage range. ${ }^{29,49-50}$

Galvanostatistic intermittent titration technique (GITT) measurements were performed to study the thermodynamic and kinetic features of the material. The open circuit voltage (OCV) curves are showed in Figure $4 \mathrm{~b}$. The OCV profile for the first charge process is totally different from that for first discharge process, implying a different reaction mechanism as often seen in other LMLO materials between lithium extraction/insertion on first cycle. ${ }^{14,51-53} \mathrm{~A}$ voltage drop, concomitant with large reaction polarization, occurs at the value of around $x=1.4$ in $\mathrm{Li}_{x} \mathrm{Ru}_{0.5} \mathrm{Mn}_{0.5} \mathrm{O}_{3}$ on discharge. The onset of voltage drop takes place at a relatively higher lithium content than that in $\mathrm{Li}_{1.2} \mathrm{Cr}_{0.4} \mathrm{Mn}_{0.4} \mathrm{O}_{2},{ }^{29}$ as reported in our previous 
work, suggesting a larger capacity can be obtained in cathode region (above $2 \mathrm{~V}$ ) for $\mathrm{Li}_{2} \mathrm{Ru} 0.5 \mathrm{Mn}_{0.5} \mathrm{O}_{3}$. These differences arise from a different phase transition pathway between $\mathrm{Li}_{1.2} \mathrm{Cr}_{0.4} \mathrm{Mn}_{0.4} \mathrm{O}_{2}$ and $\mathrm{Li}_{2} \mathrm{Ru} 0.5 \mathrm{Mn} 0.5 \mathrm{O}_{3}$ upon lithium insertion/extraction, and will be discussed in the later section. In addition, the large overpotential occurs at the end of stage III and similar to that occurs at the end of stage II, representing a slow kinetic process due to the reversible/partially reversible transition metal migration, which changes the site energy of lithium and causes large reaction hysteresis as proposed by Croy et al. ${ }^{54}$

Figure $4 \mathrm{c}$ shows the cycle performance of $\mathrm{Li}_{2} \mathrm{Ru}_{0.5} \mathrm{Mn}_{0.5} \mathrm{O}_{3}$ in the voltage range of 1-4.6 V. Strikingly, it can cycle very well with a large amount of lithium intercalation/deintercalation. The coulombic efficiency after the first cycle is around $95 \%$, and the discharge capacity retains about $250 \mathrm{mAh} \mathrm{g}^{-1}$ after 70 cycles. The decomposition of the electrolyte and side reaction at high charge voltage is partially contributed to the irreversible capacity. ${ }^{15,41}$ Rate performance was also examined and the results are shown in Figure S1. At $1 \mathrm{C}$ rate, the discharge capacity remains $60 \%$ of the capacity under $0.1 \mathrm{C}$ discharge. Such a high capacity and reversibility is unusual when compared with other layered compounds. ${ }^{4}$ The presence of Ru may increase electronic conductivity and account for the enhanced rate capability. The electrochemical performance of $\mathrm{Li}_{2} \mathrm{Ru}_{0.5} \mathrm{Mn}_{0.5} \mathrm{O}_{3}$ in the voltage range of $2.0-4.6 \mathrm{~V}$ was also tested for cathode use (Figure S2). The coulomb efficiency of the first cycle is about $73.8 \%$ and reaches $98 \%$ for the subsequent cycles. A sustained capacity retention of $207 \mathrm{mAh} \mathrm{g}^{-1}$ can be obtained for 50 cycles, similar to that reported by M. Sathiya et al. ${ }^{15}$ In addition, it displays a suppressed voltage fade than that in Li rich NMC typed $\mathrm{Li}_{1.2} \mathrm{Ni}_{0.15} \mathrm{Co}_{0.1} \mathrm{Mn}_{0.55} \mathrm{O}_{2}$ reported previously, as shown in Figure S3.

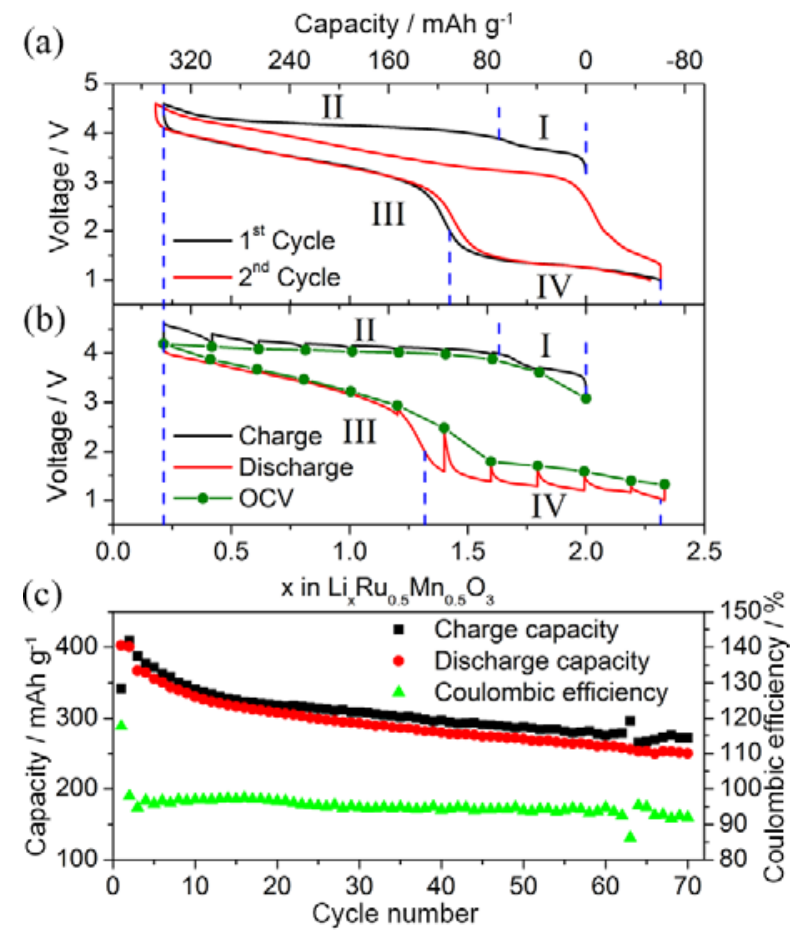

Figure 4. (a) Composition vs. voltage profiles of $\mathrm{Li}_{2} \mathrm{Ru}_{0.5} \mathrm{Mn}_{0.5} \mathrm{O}_{3} / \mathrm{Li}$ cell cycled at $0.1 \mathrm{C}\left(1 \mathrm{C}=383 \mathrm{mAh} \mathrm{g}^{-1}\right)$ rate between 1.0 and $4.6 \mathrm{~V}$ at room temperature. The curve divided into two regions on charge (I-II) and two regions on discharge (III-IV). (b) The GITT profile and open-circuit voltage curves of the $\mathrm{Li}_{2} \mathrm{Ru}_{0.5} \mathrm{Mn}_{0.5} \mathrm{O}_{3} / \mathrm{Li}$ cell during charge and discharge as a function of the Li content or capacity. (c) The cycle performance and coulombic efficiency of the cell for the first 70 cycles.

Redox mechanism investigated by in situ $\mathrm{X}$-ray absorption near edge structure (XANES). The redox reaction and the local structure change of $\mathrm{Li}_{2} \mathrm{Ru}_{0.5} \mathrm{Mn}_{0.5} \mathrm{O}_{3}$ during the first cycle and the second charge process were investigated by in situ XAS. Figure 5 shows the normalized XANES spectra for Mn and Ru K-edges, respectively. For easy interpretation, the entire electrochemical process was divided into several stages as marked on the charge-discharge curve. The spectra collected at the beginning and end of the each stage are highlighted with a thicker solid line and color encoded with the cycle labelled on the charge-discharge curve. In general, the threshold energy position of the K-edge XANES spectra of the transition metals is sensitive to their oxidation states, while the shape of the peaks is sensitive to the local structural environment of the absorbing element. The half-height energy position of the XANES spectra can be used to semi-quantitatively determine the valence state of the probing element ${ }^{4}$ which we use to track the oxidation state changes of the $\mathrm{Mn}$ and $\mathrm{Ru}$ during electrochemical cycling as shown in Figure 6.

The valence states of $\mathrm{Mn}$ and $\mathrm{Ru}$ are estimated to be $\mathrm{Mn}^{4+}$ and $\mathrm{Ru}^{4+}$ for the pristine material by comparing the XANES spectra with those of $\mathrm{Li}_{2} \mathrm{MnO}_{3}\left(\mathrm{Mn}^{4+}\right)$ and $\mathrm{RuO}_{2}\left(\mathrm{Ru}^{4+}\right)$. On the initial charge process in stage I, Ru K-edge XANES spectra clearly show an entire shift towards higher energy, while Mn K-edge XANES spectra only present a slight shape change. It indicates that oxidation of $\mathrm{Ru}^{4+}$ compensates for the charge neutrality during lithium extraction. The evolution of the Ru half-energy position shown in Figure 6 reveals that the $\mathrm{Ru}^{4+}$ has been oxidized to $\mathrm{Ru}^{5+}$ at the end of the stage $\mathrm{I}$, in good agreement with the deintercalation of $0.5 \mathrm{Li}^{+}$in this region. Upon further charging in stage II, both the $\mathrm{Mn}$ and $\mathrm{Ru}$ XANES spectra do not show rigid edge shift but only display shape changes, suggesting that the charge compensation is not taken place solely on $\mathrm{Mn}$ or $\mathrm{Ru}$ atoms but also on oxygen atoms as a result of the covalence feature of $\mathrm{Mn}-\mathrm{O}$ and $\mathrm{Ru}-\mathrm{O}$. This has also been proved by Sathiya et al. ${ }^{15,41}$ through the XPS studies that oxygen functions as an electron donor for this charging process. It is noteworthy that a much sharper increase in the pre-edge intensity for $\mathrm{Ru}(22121 \mathrm{eV})$ is observed than that for $\mathrm{Mn}(6540 \mathrm{eV})$. The pre-edge peak corresponds to the electronic transition from $1 \mathrm{~s}$ core levels to the $5 \mathrm{p}(4 \mathrm{p})$ components of $4 d(3 d)-5 p(4 p)$ hybridized states when the $\mathrm{Ru}(\mathrm{Mn}) \mathrm{O}_{6}$ octahedral distortion occurs, and the more distorted the octahedron is, the stronger the peak intensity of the pre-edge is. ${ }^{55}$ These imply that the $\mathrm{RuO}_{6}$ octahedrons in the $\mathrm{Li}_{2} \mathrm{Ru}_{0.5} \mathrm{Mn}_{0.5} \mathrm{O}_{3}$ electrode become more distorted than $\mathrm{MnO}_{6}$. Therefore, it is most likely that $\mathrm{O}$ atoms around $\mathrm{Ru}$ participate more in the oxidation process with the deintercalation of $\mathrm{Li}^{+}$, either through removal of some oxygen from the lattice with the formation of oxygen vacancies or creation of holes in oxygen $\left(\mathrm{O}^{-}\right)$. During discharge in stage III, only the XANES spectra for Ru display continuous shift to lower energy, indicating the reduction of $\mathrm{Ru}^{5+}$. The $\mathrm{Ru}^{5+}$ ions have been reduced to $\mathrm{Ru}^{4+}$ at the end of this stage, where the edge position of $\mathrm{Ru}$ XANES spectrum is close to that for pristine $\mathrm{Li}_{2} \mathrm{Ru}_{0.5} \mathrm{Mn}_{0.5} \mathrm{O}_{3}$ as shown in Figure 6. From simple electron counting, the reduction of $\mathrm{Ru}^{5+}$ to $\mathrm{Ru}^{4+}$ can only account for the reversible intercalation of $0.5 \mathrm{Li}^{+}$per unit formulas and not 1.15 as esti-

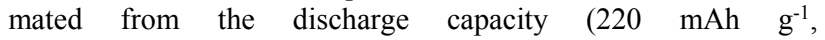
$\mathrm{Li}_{0.21} \mathrm{Ru}_{0.5} \mathrm{Mn}_{0.5} \mathrm{O}_{3}$ to $\mathrm{Li}_{1.42} \mathrm{Ru}_{0.5} \mathrm{Mn}_{0.5} \mathrm{O}_{3}$ ). Reduction of $\mathrm{O}^{-}$to $\mathrm{O}^{2-}$ must take place for the charge compensation. Upon further discharge in stage IV, XANES spectra for both Ru and Mn show a rigid shift to lower energy, indicative of simultaneous reduction of $\mathrm{Ru}$ and $\mathrm{Mn}$. Compared with standard oxides with known valence state, $\mathrm{Ru}$ ions have been found to reduce to slightly lower than $\mathrm{Ru}^{3+}$ 
at the end of discharge $\left(1.0 \mathrm{~V}, \mathrm{Li}_{2.31} \mathrm{Ru}_{0.5} \mathrm{Mn}_{0.5} \mathrm{O}_{3}\right)$, while higher than $\mathrm{Mn}^{3+}$ for $\mathrm{Mn}$ as shown in Figure 6 and Figure S4. The Mn ions become more actively involved in the redox reaction on subsequent cycling and a portion of $\mathrm{Mn}$ ions are reduced to $\mathrm{Mn}^{2+}$ after 10 cycles (Figure S5). It has also been suggested by Zhang et al. that $\mathrm{Mn}^{2+}$ species formed during the discharge process of LMLO, and could be stored in the cathode. ${ }^{56}$ This may contribute to the voltage and capacity fade in Li-rich materials. During the second charge (stage V and VI), although the voltage profile is distinct from that of the first discharge, the charge compensation process shows a very similar behavior as the first discharge process but in a reversed direction. This implies that the kinetic issues are more likely to be responsible for the asymmetric charge-discharge profile observed for most layered cathode materials cycling in a wide voltage range.

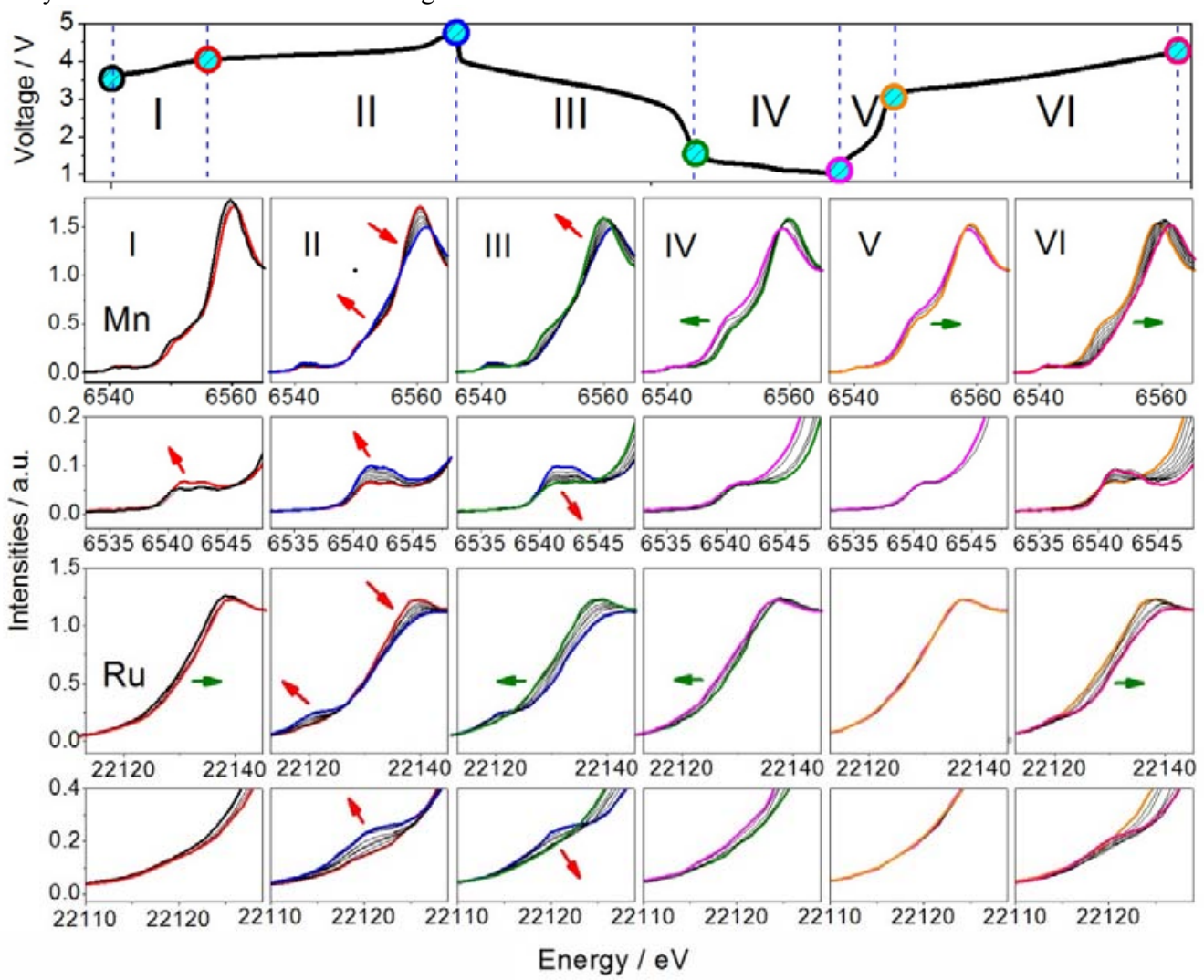

Figure 5. In situ XANES measurement of $\mathrm{Li}_{2} \mathrm{Ru}_{0.5} \mathrm{Mn}_{0.5} \mathrm{O}_{3}$ during charge-discharge process. The normalized Mn and Ru K-edge XANES spectra of $\mathrm{Li}_{x} \mathrm{Ru}_{0.5} \mathrm{Mn}_{0.5} \mathrm{O}_{3}$ during the first cycle and the second charge between 4.6 and $1.0 \mathrm{~V} \mathrm{vs}$. $\mathrm{Li}^{+} / \mathrm{Li}$ at a rate of $1 / 8 \mathrm{C}$. The entire electrochemical process was divided into several stages as marked on the charge-discharge curve. The spectra collected at the beginning and end of the each stage are highlighted with a thicker solid line and color-encoded with the cycle labelled on the charge-discharge curve. The green arrow indicates a rigid edge shift of XANES spectra, therefore representing an oxidation/reduction process taking place on the probing element. The red arrow indicates the shape and intensity change, representing the distortion of the local structure. 


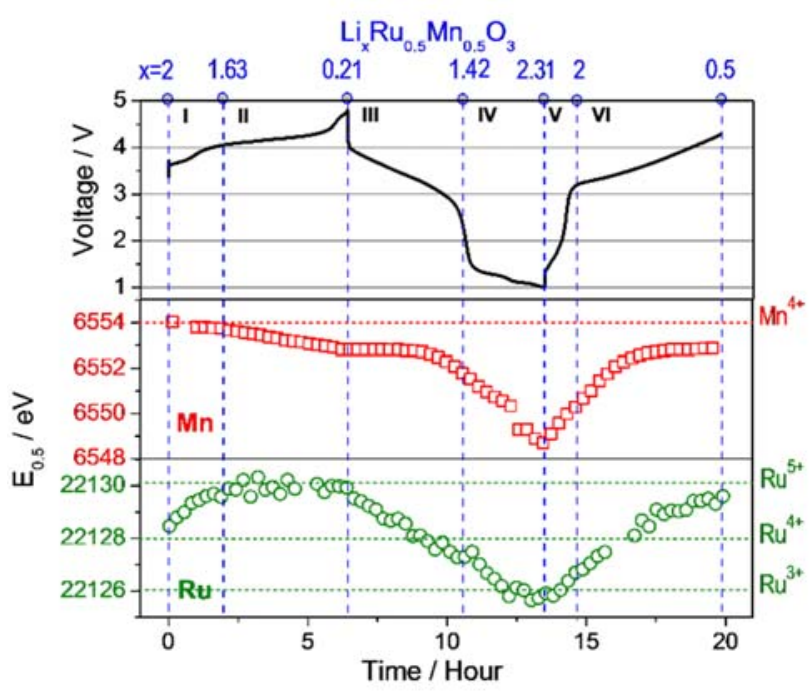

Figure 6. Variation of valence state of $\mathrm{Ru}$ and $\mathrm{Mn}$ estimated from the half-edge position of XANES spectra.

Evolution of structure over the charge-discharge process.

(1) Average crystal structure evolution investigated by in situ XRD. In situ XRD measurements were carried out to study the average structure change during the first cycle and the second charge. Figure 7a shows the selected regions of the in situ XRD patterns with the charge-discharge curve given in the right panel. (The full XRD patterns are displayed in Figure S6). The invariant peaks are caused by the inactive components of the cell (e.g. PTFE and BeO). All other peaks except those superlattice peaks are indexed using the $R \overline{3} \mathrm{~m}$ space group for easy interpretation with layered structure. In stage I, it can be seen either from the shifting of the (003) peak in Figure 5a or the fitted lattice parameters in Figure 5c that the lattice parameter " $c$ " increases. This is in accordance with previous observations in the conventional layered material (e.g. $\mathrm{LiCoO}_{2}$ ) in which the repulsion between two adjacent oxygen layers increases as lithium is deintercalated, leading to an increase in " $c$ ". Interestingly, unlike the case of conventional layered material where lattice parameter " $a$ " decreases as a result of delithiation, here an increase of " $a$ " is observed. This unconventional increase of " $a$ " has also been observed in previous studies by Sathiya et al. ${ }^{15}$ The origin of such unconventional behavior has recently been explained by Zhou et $a .^{26}$ and is attributed to the presence of metal-metal bonding. Overall, the " $a$ " and " $c$ " lattice parameters both increase during the beginning and decrease during the final of the charge, and increase during the discharge, which is the so-called unit cell breathing in layer-structured cathode materials. ${ }^{26,57}$ The structural evolution of $\mathrm{Li}_{2} \mathrm{Ru}_{0.5} \mathrm{Mnn}_{0.5} \mathrm{O}_{3}$ is quite different from that observed in $\mathrm{Li}_{2} \mathrm{RuO}_{3}$ and $\mathrm{Li}_{2} \mathrm{MnO}_{3}$. A significant peak broadening concomitant with the disappearance of the superlattice peaks is observed in stage II, suggesting either the loss of long range stacking order as suggested by recent DFT calculations ${ }^{58}$ or the loss of lithium/transition metal ordering resulting from cation rearrangement. It is worthwhile to note that peaks of $(018) /(110),(006) /(012)$ move towards each other during stage II, indicating the phase transformation from layered to disordered rock-salt or spinel structure.

During discharge on stage III, the peaks shift back to lower angles and the peak intensities increase. The clear split of the peaks of $(018) /(110),(006) /(012)$ during discharge reveal that the layered structure reformed. Superlattice peaks, originally seen in pristine material, are barely observable, indicating that lithium re-insertion cannot bring the system fully back to its original state. Overall, the structural evolution of $\mathrm{Li}_{2} \mathrm{Ru}_{0.5} \mathrm{Mn}_{0.5} \mathrm{O}_{3}$ is quite different from that observed in $\mathrm{Li}_{2} \mathrm{RuO}_{3}$ and $\mathrm{Li}_{2} \mathrm{MnO}_{3}$. For $\mathrm{Li}_{2} \mathrm{MnO}_{3}$, the "c" lattice parameter increases during the entire charge process. ${ }^{59}$ The structure changes of $\mathrm{Li}_{2} \mathrm{RuO}_{3}$ associated with lithium extraction and insertion are more complicated. In the process of lithium deintercalation, $\mathrm{Li}_{2} \mathrm{RuO}_{3}$ is transformed to different phases as monoclinic $\mathrm{Li}_{1.4} \mathrm{RuO}_{3}$ and rhombohedral $\mathrm{Li}_{0.9} \mathrm{RuO}_{3}{ }^{60}$ This phase transformation does not happen in $\mathrm{Li}_{2} \mathrm{Ru}_{0.5} \mathrm{Mn}_{0.5} \mathrm{O}_{3}$. 


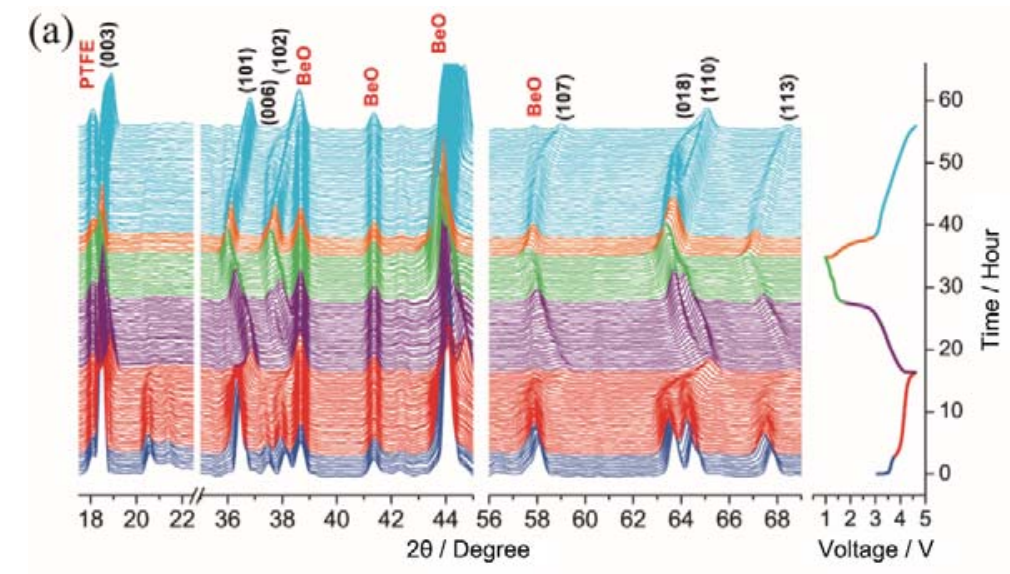

(b)

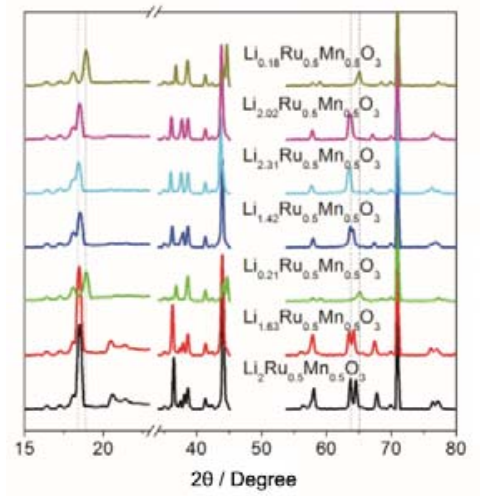

(c)

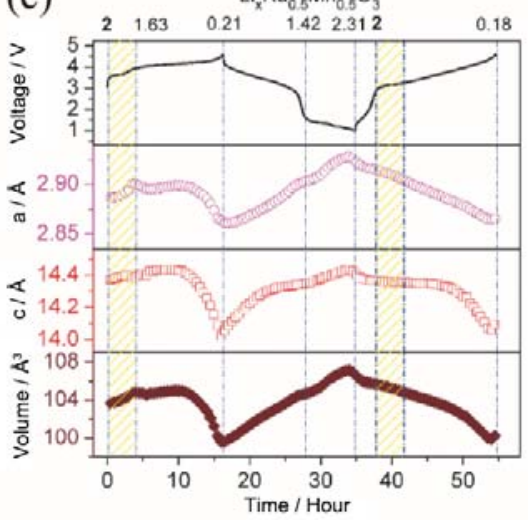

Figure 7. In situ XRD measurement of $\mathrm{Li}_{2} \mathrm{Ru}_{0.5} \mathrm{Mn}_{0.5} \mathrm{O}_{2}$ during charge-discharge process. (a) The selected regions of in situ XRD patterns of $\mathrm{Li}_{x} \mathrm{Ru}_{0.5} \mathrm{Mn}_{0.5} \mathrm{O}_{3}$ between 1.0 and $4.6 \mathrm{~V} v s$. $\mathrm{Li}^{+} / \mathrm{Li}$ during first cycle and the second charge. (b) The patterns collected at different charge and discharge states. (c) Evolution of the unit cell parameters as a function of time and the Li content. The values were derived from in situ XRD data by profile fitting using the $R \overline{3} \mathrm{~m}$ space group. The shadow mask highlights the region where abnormal lattice expansion occurs, which is only observed during the first charge process.

(2) Local structure evolution investigated by in situ extended Xray absorption fine structure (EXAFS). The EXAFS experiment is a powerful technique to determine the changes of the local structure of the selected absorbers $\mathrm{Ru}$ and $\mathrm{Mn}$ for $\mathrm{Li}_{x} \mathrm{Ru}_{0.5} \mathrm{Mn}_{0.5} \mathrm{O}_{3}$. The selected $k^{3}$ weighted Fourier transformed (FT) spectra with the uncorrected phase at the $\mathrm{Ru}$ and $\mathrm{Mn} \mathrm{K}$-edge for as prepared $\mathrm{Li}_{2} \mathrm{Ru}_{0.5} \mathrm{Mn}_{0.5} \mathrm{O}_{3}$ are shown in Figure S7 and Least-squares fits were performed (Table S1). The peak position on the FT-EXAFS plot is typically 0.3-0.4 $\AA$ shorter than the actual interatomic distance because of phase shift. A pronounced peak, located at around $2.1 \AA$ of Ru K-edge FT-EXAFS, can be assigned to short Ru-Ru dimer as previously revealed by PDF observation. The major FT peaks in $\mathrm{R}<3 \AA$ are influenced by single Metal-Metal scattering. The selected FT spectra during first charge and discharge process were presented in Figure 8. (More EXAFS spectra are shown in Figure S8). In order to collect enough XAS spectra to track the dynamic process during in situ experiment, a relatively short $\mathrm{k}$ range data was collected and thus the quantitative fitting of the spectra was not performed. The EXAFS spectra display several unique features when compared with other LMLO materials (e.g. $\mathrm{Li}_{1.2} \mathrm{Mn}_{0.54} \mathrm{Co}_{0.13} \mathrm{Ni}_{0.13} \mathrm{O}_{2},{ }^{61} \mathrm{Li}_{1.2} \mathrm{Cr}_{0.4} \mathrm{Mn}_{0.4} \mathrm{O}_{2}{ }^{29,62}$ etc.): (a) A sharp decrease in peak intensities is observed solely on $\mathrm{Ru}$ at fully charged state $\left(\mathrm{Li}_{0.21} \mathrm{Ru}_{0.5} \mathrm{Mn}_{0.5} \mathrm{O}_{3}\right)$, which suggests a significant change of the local environment around $\mathrm{Ru}$. As there is little coordination number change for the first coordination environment due to the minimal scale of oxygen loss, ${ }^{63}$ the main factor that contributes to first peak intensity reduction might be the local structural distortion. The phenomenon of a significant increase in disorder around a specific transition metal elements is not observed in NMC type lithium rich layered cathodes at charged state; ${ }^{29}, 64-65$ (b) The lithium intercalation/deintercalation process causes local changes around $\mathrm{Ru}$ and $\mathrm{Mn}$ individually. The local environment around $\mathrm{Ru}$ and $\mathrm{Mn}$ changes significantly at a deeply delithiated (charged) and lithiated (discharged) state respectively, as schematically shown in Figure $8 b$. 
(a)

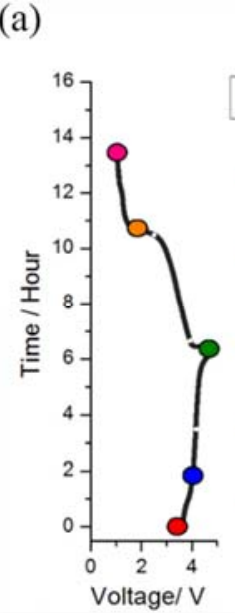

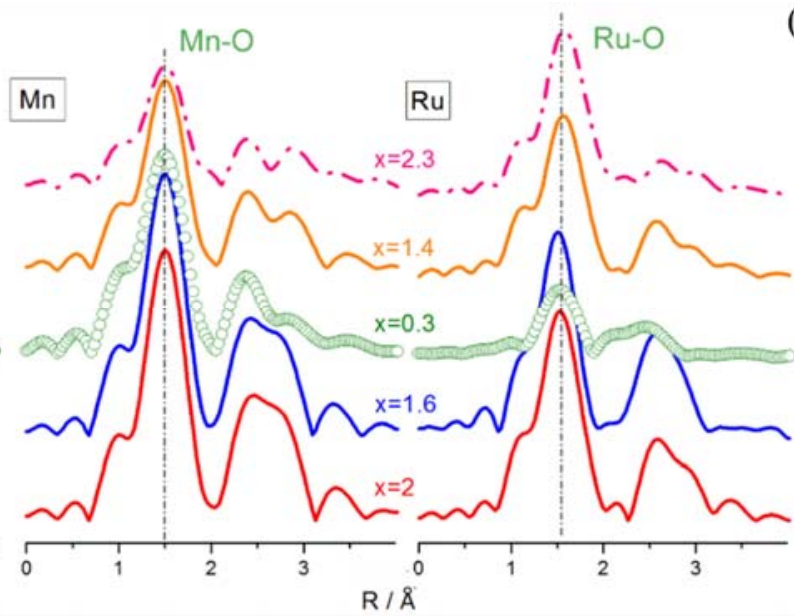

(b)

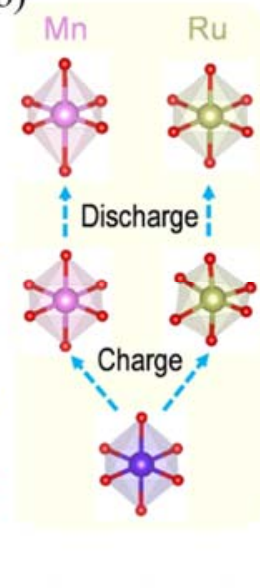

Figure 8. (a) The $k^{3}$-weighted Fourier transform magnitudes of the Mn (left) and $\mathrm{Ru}$ (right) K-edge EXAFS spectra of $\mathrm{Li}_{2} \mathrm{Ru}_{0.5} \mathrm{Mn}_{0.5} \mathrm{O}_{3}$ at different charge and discharge states. The suppressed peak intensity of Metal-Oxygen interaction represents the distortion of the the metaloxygen octahedral, which occurs at Ru site during the charge process and Mn site during the discharge process. (b) Schematics of the distorted local environment around $\mathrm{Ru}$ and $\mathrm{Mn}$ at a deeply delithiated (charged) and lithiated (discharged) state respectively.

(3) Local structure evolution probed by X-ray PDF. Unlike the EXAFS technique which can only provide very local structural information of the first several coordination shells, the PDF method is able to probe a local structure with a longer distance scale $(>30$ $\AA$ ). Ex situ PDF measurements were performed at the $1^{\text {st }}$ and $5^{\text {th }}$ cycle and the results are displayed in Figure 9. The peak position and relative intensity remain similar in both pristine and cycled $\left(1^{\text {st }}\right.$ and $5^{\text {th }}$ ) samples, showing the overall conservation of the layered structure. The slight decrease in peak intensity of the PDF curves for cycled samples is indicative of the loss of crystallinity of sample

(a) ${ }^{\mathrm{TM}} \mathrm{M}-\mathrm{O}$ TM-M

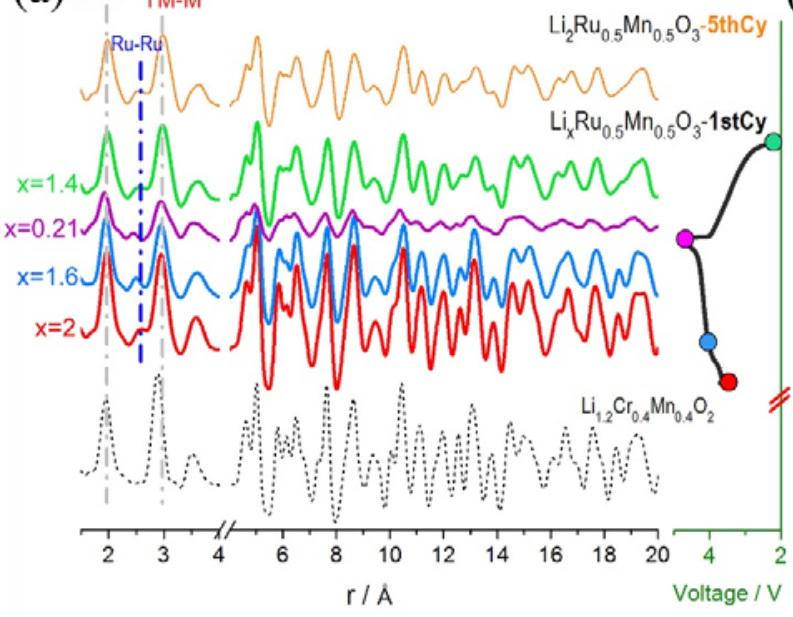

particles after the first charge and discharge process. The peak around $2.5 \AA$, due to the Ru-Ru metal-metal interaction, is observable in all PDF curves of $\mathrm{Li}_{x} \mathrm{Ru} \mathrm{u}_{0.5} \mathrm{Mn}_{0.5} \mathrm{O}_{3}$ samples. Based on the theoretic calculation of Johannes et al. in $\mathrm{Li}_{2} \mathrm{RuO}_{3},{ }^{66}$ the $\mathrm{Ru}-\mathrm{Ru}$ dimers will be destroyed along with a phase transition from monoclinic to rhombohedra symmetry upon deep delithiation, as can be seen in Figure 9b. This has not happened in $\mathrm{Li}_{2} \mathrm{Ru}_{0.5} \mathrm{Mn}_{0.5} \mathrm{O}_{3}$ and the $\mathrm{Ru}$-Ru dimerization preserves upon the entire charge-discharge process.

(b)

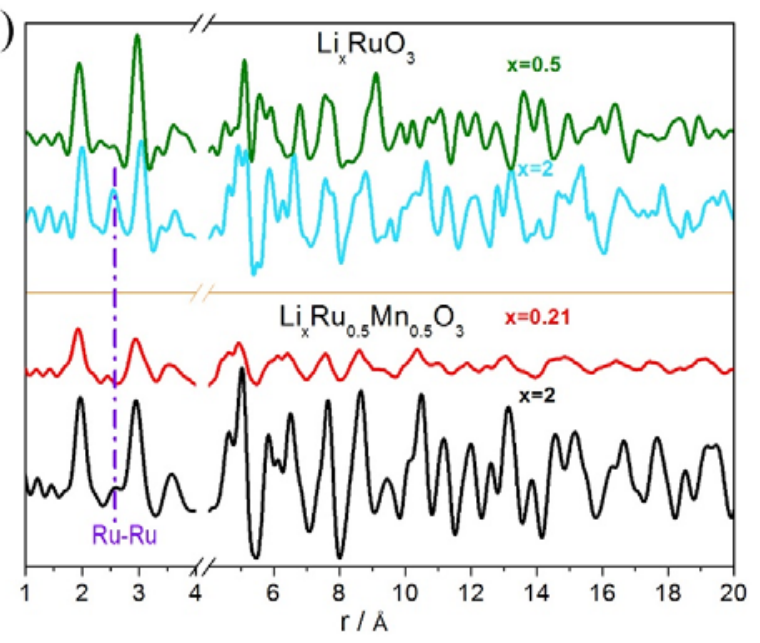

Figure 9. (a) Ex situ PDF of $\mathrm{Li}_{2} \mathrm{Ru}_{0.5} \mathrm{Mn}_{0.5} \mathrm{O}_{3}$ collected at different charge and discharge states. The dash lines correspond to the first and second coordination shell around transition metals. The peak located at $\sim 2.5 \AA$ corresponds to the Ru-Ru bonding, which exists during the entire charge-discharge process. For comparison, $\mathrm{PDF}$ of $\mathrm{Li}_{1.2} \mathrm{Cr}_{0.4} \mathrm{Mn}_{0.4} \mathrm{O}_{2}$ is displayed, which shows no sign of short Metal-Metal bond located at $\sim 2.5 \AA$. (b) Comparison of PDF results for $\mathrm{Li}_{2} \mathrm{Ru}_{0.5} \mathrm{Mn}_{0.5} \mathrm{O}_{3}$ and $\mathrm{Li}_{2} \mathrm{RuO}_{3}$ systems. $\mathrm{Ru}-\mathrm{Ru}$ dimer interaction disappears for charged $\mathrm{Li}_{2} \mathrm{RuO}_{3}\left(\mathrm{Li}_{0.5} \mathrm{RuO}_{3}\right)$ due to the phase transformation upon extraction of lithium.

(4) Atomic structure evolution probed by HAADF-STEM. HAADF-STEM experiments were further performed to understand the structural change of $\mathrm{Li}_{2} \mathrm{Ru}_{0.5} \mathrm{Mn}_{0.5} \mathrm{O}_{3}$ during charge and discharge at atomic level. The HAADF-STEM images of
$\mathrm{Li}_{2} \mathrm{Ru}_{0.5} \mathrm{Mn}_{0.5} \mathrm{O}_{3}$ at fully charged state $\left(\mathrm{Li}_{0.21} \mathrm{Ru}_{0.5} \mathrm{Mn}_{0.5} \mathrm{O}_{3}\right), 2 \mathrm{~V}$ discharged state $\left(\mathrm{Li}_{1.42} \mathrm{Ru} 0.5 \mathrm{Mn}_{0.5} \mathrm{O}_{3}\right)$ and $1 \mathrm{~V}$ discharged state $\left(\mathrm{Li}_{2.31} \mathrm{Ru}_{0.5} \mathrm{Mn}_{0.5} \mathrm{O}_{3}\right)$ are presented in Figure 10 and Figure 11.

For the fully charged sample, the "TM-TM-Li" cation ordering in the lithium/transition metal plane disappears after deep delithiation as evidenced by continuous bright dots, in good agreement with the 
in situ XRD results. Moreover, bright dots appear in the Li layers, suggesting the existence of transition metal atoms in lithium layers on the surface of the sample particle. It is likely that a portion of transition metal atoms in the lithium/transition metal plane migrates to the Li layers, resulting in the formation of a disordered structure. Migration of transition metal ions into the lithium layer to fill out the Li vacancies (or tetrahedral site) has also been observed in many other LMLO cathode materials and reported to be one of the causes for the capacity decay and voltage fading. ${ }^{9-10,67-}$ ${ }^{69}$ In addition, clear atomic images of the well crystallized layered

(a)

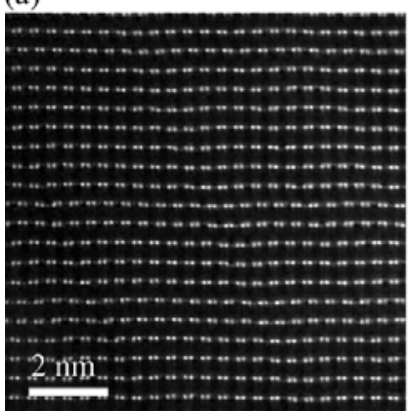

\section{(b)}

(or rock-salt) structure cannot be seen in most area of Figure 10b. This is distinct from that observed in many other lithium rich layered materials that layered or spinel framework can still be seen when lithium ions are extracted to a similar extent as in this study. The local structure in $\mathrm{Li}_{\mathrm{x}} \mathrm{Ru} 0.5 \mathrm{Mn} 0.5 \mathrm{O}_{3}$ turns highly disordered at the fully charged state, likely with microstructural defects (strain and/or size) and inhomogeneity (loss of oxygen, shear of planes, stacking faults, spinel nanodomains formation, transition metal migration, etc.). ${ }^{15}$

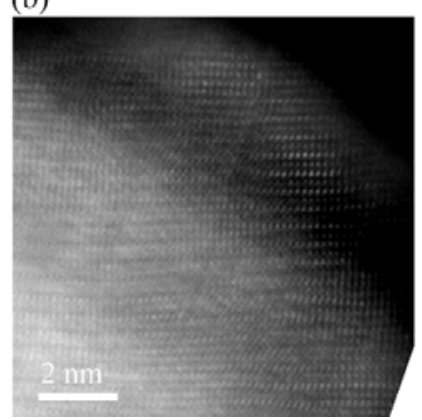

(c)

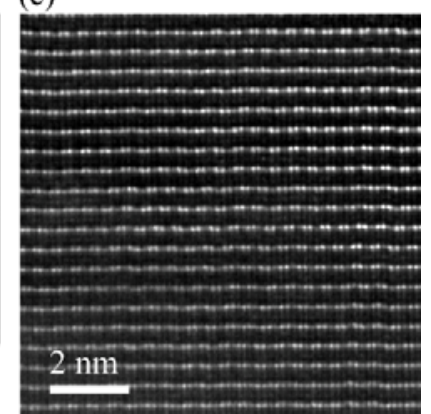

Figure 10. The HAADF-STEM images of LiRu0.5 $\mathrm{Mn}_{0.5} \mathrm{O}_{3}$ sample at (a) pristine, (b) charged state (4.6 V, Li0.21 $\left.\mathrm{Ru}_{0.5} \mathrm{Mn}_{0.5} \mathrm{O}_{3}\right)$ and (c) discharge state $\left(2 \mathrm{~V}, \mathrm{Li}_{1.42} \mathrm{Ru}_{0.5} \mathrm{Mn}_{0.5} \mathrm{O}_{3}\right)$. The images were recorded along [100] monoclinic ([1 $\left.\left.\overline{1} 12\right]_{\text {cubic }}\right)$ directions.

The HAADF-STEM image of the discharged sample at $2.0 \mathrm{~V}$ is shown in Figure 10c. The layered structure is recovered after reinsertion of lithium ions, which is supported by in situ XRD results showing that the peaks of $(018) /(110),(006) /(012)$ become separate during the discharge process. Pairs of two bright columns can be clearly seen from the transition metal layers in the image, suggesting that most of the migrated transition metal ions have moved back to the original sites as in the pristine material. Bright columns can still be seen but become much less in the Li layers. Even though the local structure experienced highly distortion and cation migration took place upon charging, the "TM-TM-Li" ordering in lithium/transition metal plane is able to be partially recovered.

The local discrepancies between 1 V discharged $\left(\mathrm{Li}_{2.31} \mathrm{Ru}_{0.5} \mathrm{Mn}_{0.5} \mathrm{O}_{3}\right)$ and the pristine sample are remarkable as shown from the HADDF-STEM images (Figure 11a). (a) The "TM-TM-Li" atomic arrangement in transition metal layers becomes much clearer as compared to that in sample at both pristine and $2.0 \mathrm{~V}$ discharged state. Furthermore, the stacking faults are barely seen, as also indicated by Fell et al. in their study of $\mathrm{Li}_{1.2} \mathrm{Ni}_{0.2} \mathrm{Mn}_{0.6} \mathrm{O}_{2}{ }^{70}$ They suggested that the oxygen framework intends to adopt a different stacking after oxygen vacancy formation and cation migration during the first charge, and such stacking changes may be responsible for the disappearance of the superstructure peaks in the XRD pattern; (b) the anti-phase domain boundary, referred to a shift of cation layers in half distance related to each other, can be observed as highlighted by the green dash rectangular box shown in Figure 11b. The formation of the anti-phase domain boundaries is often accompanied by the occurrence of a secondary phase. Because all octahedral sites are fully occupied in $\mathrm{Li}_{2} \mathrm{Ru}_{0.5} \mathrm{Mn}_{0.5} \mathrm{O}_{3}$, further lithiation necessitates the formation of another structure so as to accommodate additional lithium ions until the formation of $\mathrm{Li}_{2.31} \mathrm{Ru}_{0.5} \mathrm{Mn}_{0.5} \mathrm{O}_{3}$ at $1 \mathrm{~V}$. The new phase, determined by the high resolution synchrotron XRD, is the so called " $1 \mathrm{~T}$ " phase (space group $P \overline{3} m 1$ ) which was initially observed by Dahn et al. when lithiating $\mathrm{LiNiO}_{2}$ to yield $\mathrm{Li}_{2} \mathrm{NiO}_{2}{ }^{71}$ The distance between the transition metal layers measured directly from the STEM image is also consistent with that estimated from the structure determined from the Rietveld refinement (Figure 11c and 11d).

Anti-phase domain boundaries have been found to affect the overall lithium diffusivity in these materials. ${ }^{72}$ Zheng et al. found that antiphase domain boundaries exist in $\mathrm{LiCoO}_{2}$ thin films deposited on single-crystal sapphire substrates. ${ }^{73}$ They concluded that the domain boundaries disconnect Li-ion diffusion pathways between domains and thus are expected to have a detrimental effect on Li-ion conductivity. The DFT calculation performed by Meng et al. also suggests that the formation of anti-phase boundaries in layered $\mathrm{Li}_{2} \mathrm{MnO}_{3}$ is energetically unfavorable. ${ }^{74}$ Therefore, the anti-phase domain boundaries observed here in deeply lithiated $\mathrm{Li}_{x} \mathrm{Ru}_{0.5} \mathrm{Mn}_{0.5} \mathrm{O}_{3}$ might account for the relatively large overpotential observed in the lower discharge plateau as shown in Figure 4. 


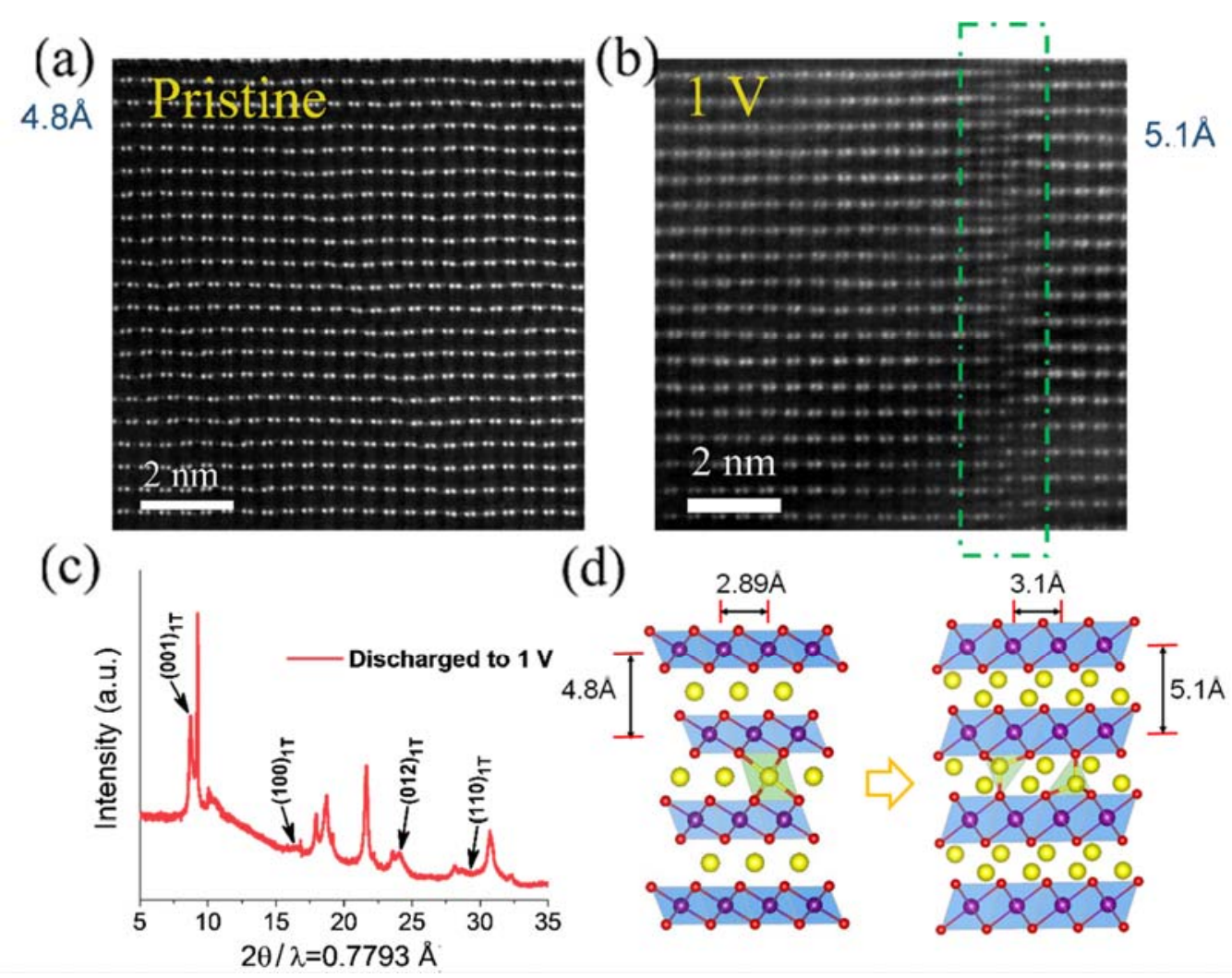

Figure 11. Phase evolution of $\mathrm{Li}_{2} \mathrm{Ru}_{0.5} \mathrm{Mn}_{0.5} \mathrm{O}_{3}$ upon discharge to $1 \mathrm{~V}$. Comparison of the HAADF-STEM images of $\mathrm{Li}_{2} \mathrm{Ru}_{0.5} \mathrm{Mn}_{0.5} \mathrm{O}_{3}$ along [100] direction between (a) the pristine and (b) $1 \mathrm{~V}$ discharged state $\left(\mathrm{Li}_{2.31} \mathrm{Ru}_{0.5} \mathrm{Mn}_{0.5} \mathrm{O}_{3}\right)$. (c) Synchrotron XRD pattern of $\mathrm{Li}_{2} \mathrm{Ru}_{0.5} \mathrm{Mn}_{0.5} \mathrm{O}_{3}$ at $1 \mathrm{~V}$ discharged state, diffraction peaks belonging to $1 \mathrm{~T}$ phase can be observed. (d) Schematic representations of the crystal structure changes associated with layered $(R \overline{3} \mathrm{~m})$ to $1 \mathrm{~T}(P \overline{3} \mathrm{~m} 1)$ phase transition. Lithium atoms are presented in yellow, transition metal are purple and oxygen atoms are red. The rearrangement of oxygen framework from $c c p$ to $h c p$ stacking is involved.

\section{- DISCUSSION}

\section{(1) Charge compensation mechanism.}

The in situ hard X-ray Mn and Ru K-edge XANES results indicate that $\mathrm{Ru}^{4+}$ is only oxidized to $\mathrm{Ru}^{5+}$ and remains unchanged or undergoes a reductive coupling process as claimed by Sathiya et al. (oxidized and self-reduced to promote the oxidation of $\left.\mathrm{O}^{2-}\right),{ }^{15}$ which cannot fully explain the large capacity observed on first charge. It is therefore unequivocally demonstrated that the lattice oxygen participates in a redox reaction to compensate the charge neutrality upon extraction of lithium at high voltage $\left(>4 \mathrm{~V} v s . \mathrm{Li}^{+} / \mathrm{Li}\right)$. This also agrees well with their findings that the creation of oxygen hole occurs on first charge and $\mathrm{O}^{2-} / \mathrm{O}^{-}$redox process contributes to the reversible capacity on subsequent cycles. ${ }^{15,41}$ It is interesting to note that the oxygen anions do not universally (or in different forms) participate in the charge compensation as indicated by the Ru Kedge EXAFS spectra. The Ru EXAFS spectra display remarkable peak suppression upon lithium extraction over the initial charge process, implying that the oxygen dimers are more likely to locate around ruthenium cations. The capacity below $2 \mathrm{~V}$ can be well explained by the reversible redox reaction occurred on both $\mathrm{Ru}$ and $\mathrm{Mn}$, though the charge-discharge curve in this region looks asymmetric. This phenomenon, being explained by Dahn and in our recent work, has been observed in other layered oxides during lithium insertion/extraction in the low voltage range. ${ }^{29,49-50}$

(2) Ru-Ru dimer effect and its relevance to structural stability.

The d electron of ruthenium ( $4 \mathrm{~d}$ transition metal) is relatively more delocalized than that of $3 \mathrm{~d}$ transition metal, ${ }^{75}$ enabling the $\mathrm{Ru}-\mathrm{Ru}$ dimerization in such a specific layered structure. ${ }^{76}$ Although the $\mathrm{Ru}-\mathrm{Ru}$ dimers are locally formed, they have global impact on the average crystal structure as well as the overall electrochemical performances. (a) The existence of Ru-Ru bonding restrains the contraction of the " $a-b$ " plane during lithium extraction as usually seen in LMLO, and the overall lattice shows abnormal lattice expansion; ${ }^{76}$ (b) Unlike the disappearance of Ru-Ru dimer in delithiated $\mathrm{Li}_{2} \mathrm{RuO}_{3}\left(\mathrm{Li}_{0} .5 \mathrm{RuO}_{3}\right), \mathrm{Ru}-\mathrm{Ru}$ dimer interaction exists over the entire charge-discharge process for $\mathrm{Li}_{2} \mathrm{Ru}_{0.5} \mathrm{Mn}_{0.5} \mathrm{O}_{3}$. The $\mathrm{Mn}$ cations act as "structural stabilizer" to tolerate the local structural changes occurring around $\mathrm{Ru}$ upon lithium extraction, without incurring phase transformations as happened in $\mathrm{Li}_{2} \mathrm{RuO}_{3} .{ }^{60}$ Meanwhile, the relatively flexible $\mathrm{Ru}-\mathrm{O}$ framework (a wide variation of $\mathrm{Ru}-\mathrm{O}$ bond distance) might favor the stabilization of oxygen holes and dimers as demonstrated by Chen and Wang, enabling the reversible utilization of oxygen related redox reactions; ${ }^{77,78}$ (c) In addition, the $\mathrm{Ru}-\mathrm{Ru}$ dimer interaction seems to favor stabilization of the phase in a perfect layered structure. Even though deep lithium extraction causes significant distortion of local structure as well as interplanar cation mixing upon charging, the entire crystal structure is able to convert back to its pristine state with the partially recovery of inplane ordering upon discharging $\left(2 \mathrm{~V}\right.$ state, $\left.\mathrm{Li}_{1.42} \mathrm{Ru}_{0.5} \mathrm{Mn}_{0.5} \mathrm{O}_{3}\right)$, as supported by in situ XRD, and ex situ STEM. Therefore the $\mathrm{Li}_{2} \mathrm{Ru}_{0.5} \mathrm{Mn}_{0.5} \mathrm{O}_{3}$ exhibits fairly good cycling performances in the cathode operating voltage range $(2-4.6 \mathrm{~V})$ in comparison to those of $\mathrm{Li}_{2} \mathrm{MnO}_{3}$ and $\mathrm{Li}_{2} \mathrm{RuO}_{3}$. $48,79-80$

(3) Phase transformation associated with overlithiation. 
The atomic resolution STEM image of discharged sample ( $\mathrm{Li}_{2.31} \mathrm{Ru}_{0.5} \mathrm{Mn}_{0.5} \mathrm{O}_{3}$ : nominal composition of $\mathrm{Li}_{1.21}\left[\mathrm{Li} 0.33 \mathrm{Ru} 0.335 \mathrm{Mn}_{0.335}\right] \mathrm{O}_{2}$ in the layered oxide form) clearly shows a region with antiphase grain boundary. This kind of dislocation can act as nucleation center for growth of a new phase, as proposed and directly observed by A. Ulvestad et al. based on their in situ Bragg coherent diffraction imaging researches on $\mathrm{LiNi}_{0.5} \mathrm{Mn}_{1.5} \mathrm{O}_{4}{ }^{74}$ Indeed, the formation of a secondary phase is unavoidable when lithiation exceeds the lithium content than that in pristine $\mathrm{Li}_{2} \mathrm{Ru}_{0.5} \mathrm{Mn}_{0.5} \mathrm{O}_{3}$. The overlithiation usually leads to growth of the $1 \mathrm{~T} \mathrm{Li}_{2} \mathrm{NiO}_{2}$ phase and accounts for the low voltage plateau on the discharge curve for most layered cathode oxides. ${ }^{81}$ The phase transformation from originally $\mathrm{O} 3$ layered structure $(\alpha-$ $\mathrm{NaFeO}_{2}$ layered structure) to $1 \mathrm{~T} \mathrm{Li}_{2} \mathrm{NiO}_{2}$ structure involves the change of the oxygen framework from $c c p$ stacking to hcp stacking and causes a large increase in the unit cell volume of around 38\%. Such phase transformation with large unit cell volume changes is kinetically not favorable for cycle and rate capability. ${ }^{82}$ However, the "layered to $1 \mathrm{~T}$ " phase transformation has not been observed in $\mathrm{Li}_{1.2} \mathrm{Cr}_{0.4} \mathrm{Mn}_{0.4} \mathrm{O}_{2}$ upon overlithiation until $\mathrm{Li}_{1.5} \mathrm{Cr}_{0.4} \mathrm{Mn}_{0.4} \mathrm{O}_{2}$ (nominal composition of $\mathrm{Li}_{1.3}\left[\mathrm{Li} 0.2 \mathrm{Cr}_{0.4} \mathrm{Mn}_{0.4}\right] \mathrm{O}_{2}$ in the layered oxide form). Because the $\mathrm{Cr}$ cation is mobile during charge and discharge, the structure is able to be stabilized in a disordered spinel phase, ${ }^{62}$ which is able to accommodate addition lithium without causing a structural change involving rearrangement of the oxygen sublattice upon overlithiation as illustrated in Figure 12. As a consequence, the $\mathrm{Li}_{1.2} \mathrm{Cr}_{0.4} \mathrm{Mn}_{0.4} \mathrm{O}_{2}$ displays better cycle performances than $\mathrm{Li}_{2} \mathrm{Ru}_{0.5} \mathrm{Mn}_{0.5} \mathrm{O}_{3}$ when cycling in a wide voltage range of $1-4.6 \mathrm{~V}$.

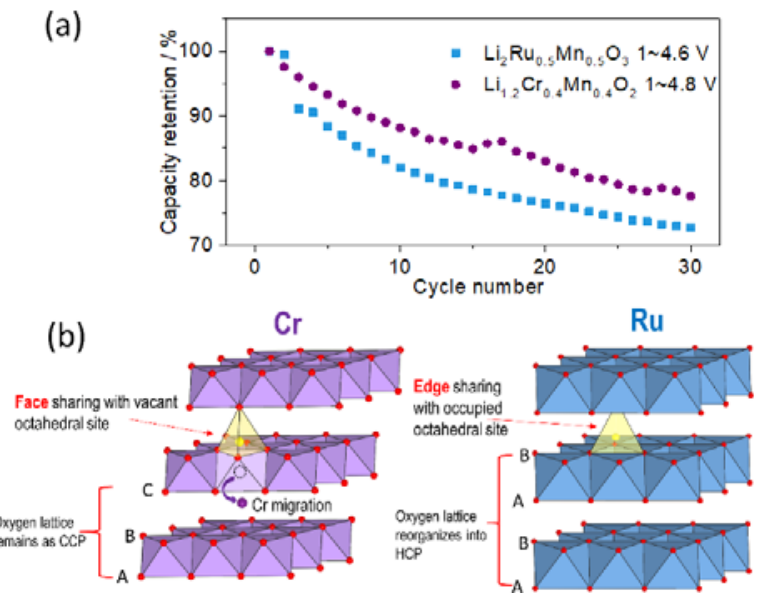

Figure 12. Phase transition at low discharge voltage $(1 \mathrm{~V})$ and its impact on electrochemical cycling performance. (a) Comparison of capacity retention between $\mathrm{Li}_{2} \mathrm{Ru}_{0.5} \mathrm{Mn}_{0.5} \mathrm{O}_{3}$ and $\mathrm{Li}_{1.2} \mathrm{Cr}_{0.4} \mathrm{Mn}_{0.4} \mathrm{O}_{2}$, cycled at a rate of $0.1 \mathrm{C}$. (b) Significant cation mixing occurs in $\mathrm{Li}_{1.2} \mathrm{Cr}_{0.4} \mathrm{Mn}_{0.4} \mathrm{O}_{2}$ after first charge-discharge process (OCV-4.8 V$1 \mathrm{~V}$ ), due to the migration of $\mathrm{Cr}$. The cation mixing favors the stabilization of the oxygen sublattice in $c c p$ stacking, other than transformation to $h c p$ stacking as observed in $\mathrm{Li}_{2} \mathrm{Ru}_{0.5} \mathrm{Mn}_{0.5} \mathrm{O}_{3}$ during deep discharge to $1 \mathrm{~V}$. Lithium atoms are presented in yellow, transition metal are light purple $(\mathrm{Cr})$ or blue $(\mathrm{Ru})$ and oxygen atoms are red in the schematic figure.

It is noteworthy that for practical use, cathode materials are not discharged to a voltage as low as $1 \mathrm{~V}\left(v s . \mathrm{Li}^{+} / \mathrm{Li}\right)$ to allow overlithiation, and as a result it is unlikely to happen under normal operating conditions. However, due to chances of the inhomogeneity of the electrochemical reaction, it is reasonable to expect some areas are more deeply lithiated than other areas, especially upon discharging at a high rate. These areas may be regarded as "locally overlithiated" and might be detrimental to the battery performances. Therefore, the investigation of the layered oxide in a wide range of lithium extraction and insertion is of vital importance for designing cathode materials with better cycle life.

\section{- CONCLUSIONS}

To sum up, a multi-faceted investigation has been carried out to study the lithium storage mechanism in $\mathrm{Li}_{2} \mathrm{Ru}_{0.5} \mathrm{Mn}_{0.5} \mathrm{O}_{3}$ and several conclusions have been achieved.

(1) $\mathrm{The} \mathrm{Li}_{2} \mathrm{Ru}_{0.5} \mathrm{Mn}_{0.5} \mathrm{O}_{3}$ has a similar average crystal structure of $\mathrm{Li}_{2} \mathrm{MnO}_{3}$, which can be described by a monoclinic phase with $\mathrm{C} 2 / \mathrm{m}$ space group. Due to the formation of Ru-Ru dimers, its local symmetry is lowered to $P 21 / m$.

(2) The $\mathrm{Ru}-\mathrm{Ru}$ dimer interaction favors the stabilization of $\mathrm{Li}_{2} \mathrm{Ru}_{0.5} \mathrm{Mn}_{0.5} \mathrm{O}_{3}$ in a perfect layered structure without interplanar cation mixing, and preserves upon prolong cycling as indicated by the PDF measurements.

(3) The charge compensation mechanism has been determined. The in situ XANES experiment confirms the oxidation of $\mathrm{Ru}^{4+}$ to $\mathrm{Ru}^{5+}$ during the charge process $(4.6 \mathrm{~V})$ and reduction of $\mathrm{Ru}^{5+}$ to $\mathrm{Ru}^{3+}$, $\mathrm{Mn}^{4+}$ to $\mathrm{Mn}^{3+}$ during the discharge process $(1 \mathrm{~V})$. The residual capacity, which cannot be explained by redox reaction on $\mathrm{Ru}$ and $\mathrm{Mn}$, is most likely due to the redox reaction on oxygen anions.

(4) The change of the local environment around $\mathrm{Ru}$ and $\mathrm{Mn}$ respond differently upon charge and discharge, and significantly affect the cycle performances associated. $\mathrm{Ru}-\mathrm{O}$ and $\mathrm{Mn}-\mathrm{O}$ octahedral become highly distorted at deeply delithiated and lithiated state respectively. The distortion of Mn-O octahedral triggers a phase transformation from layered to orthorhombic $1 \mathrm{~T}$ phase, associated with changes of the oxygen sublattice from $c c p$ stacking to hcp stacking. Such a "layered to 1T" phase transformation is not observed in $\mathrm{Li}_{1.2} \mathrm{Cr}_{0.4} \mathrm{Mn}_{0.4} \mathrm{O}_{2}$ due to the migration of $\mathrm{Cr}$ during charge and discharge. The migration of $\mathrm{Cr}$ allows the structure to be stabilized in a disordered spinel form, which is able to accommodate addition lithium without causing a structural change involving rearrangement of the oxygen sublattice. Therefore, $\mathrm{Li}_{1.2} \mathrm{Cr}_{0.4} \mathrm{Mn}_{0.4} \mathrm{O}_{2}$ shows better cycle performance than that of $\mathrm{Li}_{2} \mathrm{Ru}_{0.5} \mathrm{Mn}_{0.5} \mathrm{O}_{3}$. However, the lithium diffusion kinetics is affected due to the disordered nature of the structure.

It is obvious that different transition metal elements behave differently upon electrochemical cycling and thus affects the overall electrochemical performances of the materials in different aspects. In order to achieve high reversible lithium storage capability with reasonable lithium diffusion kinetics for layered oxide cathode materials, multi-functional elemental doping or substitution is necessary. As for $\mathrm{Ru}$, the increase of the covalence with oxygen favors the reversible redox reaction on oxygen anions. The lattice with $\mathrm{Ru}$ also seems to be more tolerant with local distortion, and therefore it is good for maintaining structural stability during long-term cycling. Although $\mathrm{Ru}$ is a precious metal, a low concentration doping is still considerable to be implemented, to enhance the structural stability of the layered oxide cathode materials for high energy density applications.

\section{ASSOCIATED CONTENT}

\section{Supporting Information}

Experimental section, electrochemical properties, in situ XRD patterns, in situ and ex situ XAS. These materials are available free of charge via the Internet at http://pubs.acs.org.

\section{AUTHOR INFORMATION}

Corresponding Authors

E-mail: xyu@iphy.ac.cn 
E-mail: 1.gu@iphy.ac.cn

E-mail: hli@iphy.ac.cn

Author Contributions

${ }^{\perp}$ Y.C. L. and E.Y. H. contributed equally. X. Yu and H. Li conceived and led the project. X. Yu and Y.C. Lyu wrote the paper with input from all authors.

ORCID

Yingchun Lyu: 0000-0003-3229-1175

Xiqian Yu: 0000-0001-8513-518X

Khalil Amine: 0000-0001-9206-3719

Lin Gu: 0000-0002-7504-031X

Hong Li: 0000-0002-8659-086X

Notes

The authors declare no competing financial interest.

\section{ACKNOWLEDGEMENT}

This work was supported by National Science Foundation of China (51325206, 51602191, 51522212, 51421002, 51672307), "Strategic Priority Research Program" of the Chinese Academy of Sciences, (Grant No. XDA09010102 and XDB07030200), Ministry of Science and Technology of China (Grants No. 2016YFB0100300) and the Key Research Program of Frontier Sciences, CAS (Grant No. QYZDB-SSW-JSC035). Enyuan $\mathrm{Hu}$ and Xiao-Qing Yang were supported by the U.S. Department of Energy, the Assistant Secretary for Energy Efficiency and Renewable Energy, Office of Vehicle Technologies through Advanced Battery Material Research (BMR) program under Contract No. DE-SC0012704. The authors acknowledge Dr. Eric Dooryhee and Dr. Jianming Bai at beamline 28-ID-2 (NSLS-II, U.S.A.), Dr. Jingyuan Ma at beamline BL14W1 (SSRF, China) and Yue Gong at Institute of Physics (CAS).

\section{- REFERENCES:}

1. Mohanty, D.; Sefat, A. S.; Li, J.; Meisner, R. A.; Rondinone, A. J.; Payzant, E. A.; Abraham, D. P.; Wood Iii, D. L.; Daniel, C., Correlating cation ordering and voltage fade in a lithium-manganese-rich lithium-ion battery cathode oxide: a joint magnetic susceptibility and TEM study. Phys. Chem. Chem. Phys. 2013, 15 (44), 19496-19509.

2. Bettge, M.; Li, Y.; Gallagher, K.; Zhu, Y.; Wu, Q.; Lu, W.; Bloom, I.; Abraham, D. P., Voltage Fade of Layered Oxides: Its Measurement and Impact on Energy Density. J. Electrochem. Soc. 2013, 160 (11), A2046-A2055.

3. Zheng, J.; Gu, M.; Genc, A.; Xiao, J.; Xu, P.; Chen, X.; Zhu, Z.; Zhao, W.; Pullan, L.; Wang, C.; Zhang, J.-G., Mitigating Voltage Fade in Cathode Materials by Improving the Atomic Level Uniformity of Elemental Distribution. Nano Lett. 2014, 14 (5), 2628-2635.

4. Yu, X.; Lyu, Y.; Gu, L.; Wu, H.; Bak, S.-M.; Zhou, Y.; Amine, K.; Ehrlich, S. N.; Li, H.; Nam, K.-W.; Yang, X.-Q., Understanding the Rate Capability of High-Energy-Density Li-Rich Layered $\mathrm{Li}_{1.2} \mathrm{Ni}_{0.15} \mathrm{Co}_{0.1} \mathrm{Mn}_{0.55} \mathrm{O}_{2}$ Cathode Materials. Adv. Energy Mater. 2014, 4 (5), 1300950.

5. Thackeray, M. M.; Johnson, C. S.; Vaughey, J. T.; Li, N.; Hackney, S. A., Advances in manganese-oxide 'composite' electrodes for lithium-ion batteries. J. Mater. Chem. 2005, 15 (23), 2257-2267.

6. Jiang, J.; Dahn, J. R., Insignificant impact of designed oxygen release from high capacity $\mathrm{Li}\left[\left(\mathrm{Ni}_{1 / 2} \mathrm{Mn}_{1 / 2}\right)_{\mathrm{x}} \mathrm{Co}_{\mathrm{y}}\left(\mathrm{Li}_{1 / 3} \mathrm{Mn}_{2 / 3}\right)_{1 / 3}\right] \mathrm{O}_{2}$ positive electrodes during the cycling of Li-ion cells. Electrochim. Acta 2006, 51 (17), 3413-3416.

7. Meng, Y. S.; Ceder, G.; Grey, C. P.; Yoon, W. S.; Jiang, M.; Bréger, J.; Shao-Horn, Y., Cation Ordering in Layered O3 $\mathrm{Li}^{2} \mathrm{Ni}_{\mathrm{x}} \mathrm{Li}_{1 / 3}$ $\left.2 \mathrm{x} / 3 \mathrm{Mn}_{2 / 3-\mathrm{x} / 3}\right] \mathrm{O}_{2}(0 \leq \mathrm{x} \leq 1 / 2)$ Compounds. Chem. Mater. 2005, 17 (9), 2386-2394.

8. Mohanty, D.; Kalnaus, S.; Meisner, R. A.; Rhodes, K. J.; Li, J.; Payzant, E. A.; Wood Iii, D. L.; Daniel, C., Structural transformation of a lithium-rich $\mathrm{Li}_{1.2} \mathrm{Co}_{0.1} \mathrm{Mn}_{0.55} \mathrm{Ni}_{0.15} \mathrm{O}_{2}$ cathode during high voltage cycling resolved by in situ X-ray diffraction. J. Power Sources 2013, 229 (0), 239-248.

9. Gu, M.; Belharouak, I.; Zheng, J.; Wu, H.; Xiao, J.; Genc, A.; Amine, K.; Thevuthasan, S.; Baer, D. R.; Zhang, J.-G.; Browning, N. D.; Liu, J.; Wang, C., Formation of the Spinel Phase in the Layered Composite Cathode Used in Li-Ion Batteries. ACS Nano 2013, 7 (1), 760-767.

10. Gu, M.; Genc, A.; Belharouak, I.; Wang, D.; Amine, K.; Thevuthasan, S.; Baer, D. R.; Zhang, J.-G.; Browning, N. D.; Liu, J.; Wang, C., Nanoscale Phase Separation, Cation Ordering, and Surface Chemistry in Pristine $\mathrm{Li}_{1.2} \mathrm{Ni}_{0.2} \mathrm{Mn}_{0.6} \mathrm{O}_{2}$ for Li-Ion Batteries. Chem. Mater. 2013, 25 (11), 2319-2326.

11. Jarvis, K. A.; Wang, C.-C.; Manthiram, A.; Ferreira, P. J., The role of composition in the atomic structure, oxygen loss, and capacity of layered Li-Mn-Ni oxide cathodes. J. Mater. Chem. A 2014, 2 (5), 1353-1362.

12. Salager, E.; Sarou-Kanian, V.; Sathiya, M.; Tang, M.; Leriche, J.-B.; Melin, P.; Wang, Z.; Vezin, H.; Bessada, C.; Deschamps, M.; Tarascon, J.-M., Solid-State NMR of the Family of Positive Electrode Materials $\mathrm{Li}_{2} \mathrm{Ru}_{1-\mathrm{y}} \mathrm{Sn}_{\mathrm{y}} \mathrm{O}_{3}$ for Lithium-Ion Batteries. Chem. Mater. 2014, 26 (24), 7009-7019.

13. McCalla, E.; Abakumov, A. M.; Saubanère, M.; Foix, D.; Berg, E. J.; Rousse, G.; Doublet, M.-L.; Gonbeau, D.; Novák, P.; Van Tendeloo, G.; Dominko, R.; Tarascon, J.-M., Visualization of O-O peroxo-like dimers in high-capacity layered oxides for Li-ion batteries. Science 2015, 350 (6267), 1516-1521.

14. Armstrong, A. R.; Holzapfel, M.; Novák, P.; Johnson, C. S.; Kang, S.-H.; Thackeray, M. M.; Bruce, P. G., Demonstrating Oxygen Loss and Associated Structural Reorganization in the Lithium Battery Cathode $\mathrm{Li}\left[\mathrm{Ni}_{0.2} \mathrm{Li}_{0.2} \mathrm{Mn}_{0.6}\right] \mathrm{O}_{2}$. J. Am. Chem. Soc. 2006, 128 (26), 8694 8698 .

15. Sathiya, M.; Ramesha, K.; Rousse, G.; Foix, D.; Gonbeau, D.; Prakash, A. S.; Doublet, M. L.; Hemalatha, K.; Tarascon, J. M., High Performance $\mathrm{Li}_{2} \mathrm{Ru}_{1-\mathrm{y}} \mathrm{Mn}_{\mathrm{y}} \mathrm{O}_{3}(0.2 \leq \mathrm{y} \leq 0.8)$ Cathode Materials for Rechargeable Lithium-Ion Batteries: Their Understanding. Chem. Mater. 2013, 25 (7), 1121-1131.

16. Saubanere, M.; McCalla, E.; Tarascon, J. M.; Doublet, M. L., The intriguing question of anionic redox in high-energy density cathodes for Li-ion batteries. Energy Environ. Sci. 2016, 9, 984-991.

17. Luo, K.; Roberts, M. R.; Hao, R.; Guerrini, N.; Pickup, D. M.; Liu, Y.-S.; Edström, K.; Guo, J.; Chadwick, A. V.; Duda, L. C.; Bruce, P. G., Charge-compensation in 3d-transition-metal-oxide intercalation cathodes through the generation of localized electron holes on oxygen. Nat. Chem. 2016, 8 (7), 684-691.

18. Seo, D.-H.; Lee, J.; Urban, A.; Malik, R.; Kang, S.; Ceder, G., The structural and chemical origin of the oxygen redox activity in layered and cation-disordered Li-excess cathode materials. Nat. Chem. 2016, 8 (7), 692-697.

19. Yabuuchi, N.; Nakayama, M.; Takeuchi, M.; Komaba, S.; Hashimoto, Y.; Mukai, T.; Shiiba, H.; Sato, K.; Kobayashi, Y.; Nakao, A.; Yonemura, M.; Yamanaka, K.; Mitsuhara, K.; Ohta, T., Origin of stabilization and destabilization in solid-state redox reaction of oxide ions for lithium-ion batteries. Nat. Commun. 2016, 7, 13814

20. Grimaud, A.; Hong, W. T.; Shao-Horn, Y.; Tarascon, J. M., Anionic redox processes for electrochemical devices. Nat. Mater. 2016, 15 (2), 121-126.

21. Xu, Y.; Hu, E.; Yang, F.; Corbett, J.; Sun, Z.; Lyu, Y.; Yu, X.; Liu, Y.; Yang, X.-Q.; Li, H., Structural integrity-Searching the key factor to supress the voltage fade of Li-rich layered cathode materials through 3D X-ray imaging and spectroscopy techniques. Nano Energy 2016, 28, 164-171.

22. Hu, E.; Lyu, Y.; Xin, H. L.; Liu, J.; Han, L.; Bak, S.-M.; Bai, J.; Yu, X.; Li, H.; Yang, X.-Q., Explore the Effects of Microstructural Defects on Voltage Fade of Li- and Mn-Rich Cathodes. Nano Lett. 2016, 16 (10), 5999-6007. 
23. Zheng, J.; Myeong, S.; Cho, W.; Yan, P.; Xiao, J.; Wang, C.; Cho, J.; Zhang, J.-G., Li- and Mn-Rich Cathode Materials: Challenges to Commercialization. Adv. Energy Mater. 2017, 1601284.

24. Yabuuchi, N.; Yamamoto, K.; Yoshii, K.; Nakai, I.; Nishizawa, T.; Omaru, A.; Toyooka, T.; Komaba, S., Structural and Electrochemical Characterizations on $\mathrm{Li}_{2} \mathrm{MnO}_{3}-\mathrm{LiCoO}_{2}-\mathrm{LiCrO}_{2}$ System as Positive Electrode Materials for Rechargeable Lithium Batteries. J. Electrochem. Soc. 2013, 160 (1), A39-A45.

25. Ma, J.; Zhou, Y.-N.; Gao, Y.; Yu, X.; Kong, Q.; Gu, L.; Wang, Z.; Yang, X.-Q.; Chen, L., Feasibility of Using $\mathrm{Li}_{2} \mathrm{MoO}_{3}$ in Constructing Li-Rich High Energy Density Cathode Materials. Chem. Mater. 2014, 26 (10), 3256-3262.

26. Zhou, Y.-N.; Ma, J.; Hu, E.; Yu, X.; Gu, L.; Nam, K.-W.; Chen, L.; Wang, Z.; Yang, X.-Q., Tuning charge - discharge induced unit cell breathing in layer-structured cathode materials for lithium-ion batteries. Nat. Commun. 2014, 5, 5381 .

27. Yabuuchi, N.; Takeuchi, M.; Nakayama, M.; Shiiba, H.; Ogawa, M.; Nakayama, K.; Ohta, T.; Endo, D.; Ozaki, T.; Inamasu, T.; Sato, K.; Komaba, S., High-capacity electrode materials for rechargeable lithium batteries: $\mathrm{Li}_{3} \mathrm{NbO}_{4}$-based system with cation-disordered rocksalt structure. Proc. Natl. Acad. Sci. 2015, 112 (25), 7650 - 7655.

28. Mori, D.; Sakaebe, H.; Shikano, M.; Kojitani, H.; Tatsumi, K.; Inaguma, Y., Synthesis, phase relation and electrical and electrochemical properties of ruthenium-substituted $\mathrm{Li}_{2} \mathrm{MnO}_{3}$ as a novel cathode material. J. Power Sources 2011, 196 (16), 6934-6938.

29. Lyu, Y.; Zhao, N.; Hu, E.; Xiao, R.; Yu, X.; Gu, L.; Yang, X.-Q.; Li, H., Probing Reversible Multi-electron Transfer and Structure Evolution of $\mathrm{Li}_{1.2} \mathrm{Cr}_{0.4} \mathrm{Mn}_{0.4} \mathrm{O}_{2}$ Cathode Material for Li-ion Batteries in a Voltage Range of 1.0-4.8 V. Chem. Mater. 2015, 27 (15), 5238-5252.

30. Lee, J.; Urban, A.; Li, X.; Su, D.; Hautier, G.; Ceder, G., Unlocking the Potential of Cation-Disordered Oxides for Rechargeable Lithium Batteries. Science 2014, 343 (6170), 519-522.

31. Mi, X.; Li, H.; Huang, X., Electrochemical and structural studies of the carbon-coated $\operatorname{LiCr}_{x} \operatorname{Li}_{(1 / 3-x / 3)} \mathrm{Ti}_{(2 / 3-2 x / 3)} \mathrm{O}_{2}(\mathrm{x}=0.3,0.35,0.4$, 0.45). J. Power Sources 2007, 174 (2), 867-871.

32. Yu, S.-H.; Yoon, T.; Mun, J.; Park, S.; Kang, Y.-S.; Park, J.H.; Oh, S. M.; Sung, Y.-E., Continuous activation of $\mathrm{Li}_{2} \mathrm{MnO}_{3}$ component upon cycling in $\mathrm{Li}_{1.167} \mathrm{Ni}_{0.233} \mathrm{Co}_{0.100} \mathrm{Mn}_{0.467} \mathrm{Mo}_{0.033} \mathrm{O}_{2}$ cathode material for lithium ion batteries. J. Mater. Chem. A 2013, 1 (8), 28332839 .

33. Song, B.; Lai, M. O.; Lu, L., Influence of Ru substitution on Li-rich $0.55 \mathrm{Li}_{2} \mathrm{MnO}_{3} \cdot 0.45 \mathrm{LiNi}_{1 / 3} \mathrm{Co}_{1 / 3} \mathrm{Mn}_{1 / 3} \mathrm{O}_{2}$ cathode for $\mathrm{Li}$-ion batteries. Electrochim. Acta 2012, 80, 187-195.

34. Sathiya, M.; Abakumov, A. M.; Foix, D.; Rousse, G.; Ramesha, K.; Saubanère, M.; Doublet, M. L.; Vezin, H.; Laisa, C. P.; Prakash, A. S.; Gonbeau, D.; VanTendeloo, G.; Tarascon, J. M., Origin of voltage decay in high-capacity layered oxide electrodes. Nat. Mater. 2014, 14 (2), 230 - 238 .

35. Jarvis, K. A.; Deng, Z. Q.; Allard, L. F.; Manthiram, A.; Ferreira, P. J., Atomic Structure of a Lithium-Rich Layered Oxide Material for Lithium-Ion Batteries: Evidence of a Solid Solution. Chem. Mater. 2011, 23 (16), 3614-3621.

36. Xu, B.; Fell, C. R.; Chi, M.; Meng, Y. S., Identifying surface structural changes in layered Li-excess nickel manganese oxides in high voltage lithium ion batteries: A joint experimental and theoretical study. Energy Environ. Sci. 2011, 4 (6), 2223-2233.

37. Yu, H.; Ishikawa, R.; So, Y.-G.; Shibata, N.; Kudo, T.; Zhou, H.; Ikuhara, Y., Direct Atomic-Resolution Observation of Two Phases in the $\mathrm{Li}_{1.2} \mathrm{Mn}_{0.567} \mathrm{Ni}_{0.166} \mathrm{Co}_{0.067} \mathrm{O}_{2}$ Cathode Material for Lithium-Ion Batteries. Angew. Chem. Int. Ed. 2013, 52 (23), 5969-5973.

38. Boulineau, A.; Simonin, L.; Colin, J.-F.; Canevet, E.; Daniel, L.; Patoux, S., Evolutions of $\mathrm{Li}_{1.2} \mathrm{Mn}_{0.61} \mathrm{Ni}_{0.18} \mathrm{Mg}_{0.01} \mathrm{O}_{2}$ during the Initial Charge/Discharge Cycle Studied by Advanced Electron Microscopy. Chem. Mater. 2012, 24 (18), 3558-3566.

39. Wen, J. G.; Bareño, J.; Lei, C. H.; Kang, S. H.; Balasubramanian, M.; Petrov, I.; Abraham, D. P., Analytical electron microscopy of $\mathrm{Li}_{1.2} \mathrm{Co}_{0.4} \mathrm{Mn}_{0.4} \mathrm{O}_{2}$ for lithium-ion batteries. Solid State Ionics 2011, 182 (1), 98-107.
40. Yu, H.; Kim, H.; Wang, Y.; He, P.; Asakura, D.; Nakamura Y.; Zhou, H., High-energy 'composite' layered manganese-rich cathode materials via controlling $\mathrm{Li}_{2} \mathrm{MnO}_{3}$ phase activation for lithium-ion batteries. Phys. Chem. Chem. Phys. 2012, 14 (18), 6584-6595.

41. Sathiya, M.; Rousse, G.; Ramesha, K.; Laisa, C. P.; Vezin, H.; Sougrati, M. T.; Doublet, M. L.; Foix, D.; Gonbeau, D.; Walker, W.; Prakash, A. S.; Ben Hassine, M.; Dupont, L.; Tarascon, J. M., Reversible anionic redox chemistry in high-capacity layered-oxide electrodes. Nat. Mater. 2013, 12 (9), 827-835.

42. Boulineau, A.; Croguennec, L.; Delmas, C.; Weill, F., Reinvestigation of $\mathrm{Li}_{2} \mathrm{MnO}_{3}$ Structure: Electron Diffraction and High Resolution TEM. Chem. Mater. 2009, 21 (18), 4216-4222.

43. Boulineau, A.; Croguennec, L.; Delmas, C.; Weill, F., Structure of $\mathrm{Li}_{2} \mathrm{MnO}_{3}$ with different degrees of defects. Solid State Ionics 2010, 180 (40), 1652-1659.

44. Rietveld, H. M., A profile refinement method for nuclear and magnetic structures. J. Appl. Crystallogr. 1969, 2 (2), 65-71.

45. Miura, Y.; Yasui, Y.; Sato, M.; Igawa, N.; Kakurai, K., NewType Phase Transition of $\mathrm{Li}_{2} \mathrm{RuO}_{3}$ with Honeycomb Structure. J. Phys. Soc. Jpn. 2007, 76 (3), 033705.

46. Kimber, S. A. J.; Mazin, I. I.; Shen, J.; Jeschke, H. O.; Streltsov, S. V.; Argyriou, D. N.; Valentí, R.; Khomskii, D. I., Valence bond liquid phase in the honeycomb lattice material $\mathrm{Li}_{2} \mathrm{RuO}_{3}$. Phys. Rev. B 2014, 89 (8), 081408.

47. Lyu, Y.; Ben, L.; Sun, Y.; Tang, D.; Xu, K.; Gu, L.; Xiao, R.; Li, H.; Chen, L.; Huang, X., Atomic insight into electrochemical inactivity of lithium chromate $\left(\mathrm{LiCrO}_{2}\right)$ : Irreversible migration of chromium into lithium layers in surface regions. J. Power Sources 2015 , 273 (1), 1218-1225

48. Wang, R.; He, X.; He, L.; Wang, F.; Xiao, R.; Gu, L.; Li, H.; Chen, L., Atomic Structure of $\mathrm{Li}_{2} \mathrm{MnO}_{3}$ after Partial Delithiation and Re-Lithiation. Adv. Energy Mater. 2013, 3 (10), 1358-1367.

49. Johnson, C. S.; Kim, J.-S.; Jeremy Kropf, A.; Kahaian, A. J.; Vaughey, J. T.; Thackeray, M. M., The role of $\mathrm{Li}_{2} \mathrm{MO}_{2}$ structures $(\mathrm{M}=$ metal ion) in the electrochemistry of $(\mathrm{x}) \mathrm{LiMn}_{0.5} \mathrm{Ni}_{0.5} \mathrm{O}_{2} \cdot(1-\mathrm{x}) \mathrm{Li}_{2} \mathrm{TiO}_{3}$ electrodes for lithium-ion batteries. Electrochem. Commun. 2002, 4 (6), 492-498.

50. Moore, G. J.; Johnson, C. S.; Thackeray, M. M., The electrochemical behavior of $x \mathrm{LiNiO}_{2}(1-\mathrm{x}) \mathrm{Li}_{2} \mathrm{RuO}_{3}$ and $\mathrm{Li}_{2} \mathrm{Ru}_{1-\mathrm{y}} \mathrm{Zr}_{\mathrm{y}} \mathrm{O}_{3}$ electrodes in lithium cells. J. Power Sources 2003, 119, 216-220.

51. Thackeray, M. M.; Kang, S.-H.; Johnson, C. S.; Vaughey, J. T.; Benedek, R.; Hackney, S. A., $\mathrm{Li}_{2} \mathrm{MnO}_{3}$-stabilized $\mathrm{LiMO}_{2}(\mathrm{M}=\mathrm{Mn}$, $\mathrm{Ni}, \mathrm{Co}$ ) electrodes for lithium-ion batteries. J. Mater. Chem. 2007, 17 (30), 3112-3125.

52. Yabuuchi, N.; Yoshii, K.; Myung, S.-T.; Nakai, I.; Komaba, S., Detailed Studies of a High-Capacity Electrode Material for Rechargeable Batteries, $\mathrm{Li}_{2} \mathrm{MnO}_{3}-\mathrm{LiCo}_{1 / 3} \mathrm{Ni}_{1 / 3} \mathrm{Mn}_{1 / 3} \mathrm{O}_{2}$. J. Am. Chem. Soc. 2011, 133 (12), 4404-4419.

53. Wang, Y.; Bie, X.; Nikolowski, K.; Ehrenberg, H.; Du, F.; Hinterstein, M.; Wang, C.; Chen, G.; Wei, Y., Relationships between Structural Changes and Electrochemical Kinetics of Li-Excess $\mathrm{Li}_{1.13} \mathrm{Ni}_{0.3} \mathrm{Mn}_{0.57} \mathrm{O}_{2}$ during the First Charge. J. Phys. Chem. C 2013, 117 (7), 3279-3286.

54. Croy, J. R.; Gallagher, K. G.; Balasubramanian, M.; Chen, Z.; Ren, Y.; Kim, D.; Kang, S. H.; Dees, D. W.; Thackeray, M. M., Examing hysteresis in composite $\mathrm{xLi}_{2} \mathrm{MnO}_{3} \cdot(1-\mathrm{x}) \mathrm{LiMO}_{2}$ cathode structures. J. Phys. Chem. C 2013, 117(13), 6525-6536.

55. Getty, K.; Delgado-Jaime, M. U.; Kennepohl, P., Assignment of pre-edge features in the Ru K-edge X-ray absorption spectra of organometallic ruthenium complexes. Inorg. Chim. Acta 2008, 361 (4), 1059-1065.

56. Zheng, J.; Gu, M.; Xiao, J.; Zuo, P.; Wang, C.; Zhang, J.-G., Corrosion/Fragmentation of Layered Composite Cathode and Related Capacity/Voltage Fading during Cycling Process. Nano Lett. 2013, 13 (8), 3824-3830.

57. Besenhard, J. O., Handbook of battery materials. John Wiley \& Sons: 2008.

58. Xiao, R.; Li, H.; Chen, L., Density Functional Investigation on $\mathrm{Li}_{2} \mathrm{MnO}_{3}$. Chem. Mater. 2012, 24 (21), 4242-4251. 
59. Yu, D. Y. W.; Yanagida, K.; Kato, Y.; Nakamura, H., Electrochemical Activities in $\mathrm{Li}_{2} \mathrm{MnO}_{3}$. J. Electrochem. Soc. 2009, 156 (6), A417-A424.

60. Kobayashi, H.; Kanno, R.; Kawamoto, Y.; Tabuchi, M.; Nakamura, O.; Takano, M., Structure and lithium deintercalation of $\mathrm{Li}_{2-\mathrm{x}} \mathrm{RuO}_{3}$. Solid State Ionics 1995, 82 (1-2), 25-31.

61. Koga, H.; Croguennec, L.; Ménétrier, M.; Mannessiez, P.; Weill, F.; Delmas, C.; Belin, S., Operando X-ray Absorption Study of the Redox Processes Involved upon Cycling of the Li-Rich Layered Oxide $\mathrm{Li}_{1.20} \mathrm{Mn}_{0.54} \mathrm{Co}_{0.13} \mathrm{Ni}_{0.13} \mathrm{O}_{2}$ in Li Ion Batteries. J. Phys. Chem. C 2014, 118 (11), 5700-5709.

62. Balasubramanian, M.; McBreen, J.; Davidson, I. J.; Whitfield, P. S.; Kargina, I., In situ X-ray absorption study of a layered manganese-chromium oxide-based cathode material. J. Electrochem. Soc. 2002, 149 (2), A176-A184.

63. Croy, J. R.; Iddir, H.; Gallagher, K.; Johnson, C. S.; Benedek, R.; Balasubramanian, M., First-charge instabilities of layered-layered lithium-ion-battery materials. Phys. Chem. Chem. Phys. 2015, 17 (37), 24382-24391.

64. Simonin, L.; Colin, J.-F.; Ranieri, V.; Canevet, E.; Martin, J.-F.; Bourbon, C.; Baehtz, C.; Strobel, P.; Daniel, L.; Patoux, S., In situ investigations of a Li-rich $\mathrm{Mn}-\mathrm{Ni}$ layered oxide for $\mathrm{Li}$-ion batteries. J. Mater. Chem. 2012, 22 (22), 11316-11322.

65. Ito, A.; Sato, Y.; Sanada, T.; Hatano, M.; Horie, H.; Ohsawa, Y., In situ X-ray absorption spectroscopic study of Li-rich layered cathode material $\mathrm{Li}\left[\mathrm{Ni}_{0.17} \mathrm{Li}_{0.2} \mathrm{Co}_{0.07} \mathrm{Mn}_{0.56}\right] \mathrm{O}_{2}$. J. Power Sources 2011, 196 (16), 6828-6834.

66. Johannes, M. D.; Stux, A. M.; Swider-Lyons, K. E., Electronic structure and properties of Li-insertion materials: $\mathrm{Li}_{2} \mathrm{RuO}_{3}$ and $\mathrm{RuO}_{2}$. Phys. Rev. B 2008, 77 (7), 075124.

67. Nayak, P. K.; Grinblat, J.; Levi, M.; Markovsky, B.; Aurbach, D., Structural and Electrochemical Evidence of Layered to Spinel Phase Transformation of Li and Mn Rich Layered Cathode Materials of the Formulae $x \mathrm{Li}\left[\mathrm{Li}_{1 / 3} \mathrm{Mn}_{2 / 3}\right] \mathrm{O}_{2} \cdot(1-\mathrm{x}) \mathrm{LiMn}_{1 / 3} \mathrm{Ni}_{1 / 3} \mathrm{Co}_{1 / 3} \mathrm{O}_{2}(\mathrm{x}$ $=0.2,0.4,0.6)$ upon Cycling. J. Electrochem. Soc. 2014, 161 (10), A1534-A1547.

68. Ito, A.; Shoda, K.; Sato, Y.; Hatano, M.; Horie, H.; Ohsawa, Y., Direct observation of the partial formation of a framework structure for $\mathrm{Li}$-rich layered cathode material $\mathrm{Li} \mathrm{Ni}_{0.17} \mathrm{Li}_{0.2} \mathrm{Co}_{0.07} \mathrm{Mn}_{0.56} \mathrm{O}_{2}$ upon the first charge and discharge. J. Power Sources 2011, 196 (10), 47854790 .

69. Zheng, J.; Xu, P.; Gu, M.; Xiao, J.; Browning, N. D.; Yan, P.; Wang, C.; Zhang, J.-G., Structural and Chemical Evolution of Liand Mn-Rich Layered Cathode Material. Chem. Mater. 2015, 27 (4), 1381-1390.

70. Fell, C. R.; Qian, D.; Carroll, K. J.; Chi, M.; Jones, J. L.; Meng, Y. S., Correlation Between Oxygen Vacancy, Microstrain, and Cation Distribution in Lithium-Excess Layered Oxides During the First Electrochemical Cycle. Chem. Mater. 2013, 25 (9), 1621-1629.
71. Dahn, J. R.; von Sacken, U.; Michal, C. A., Structure and electrochemistry of $\mathrm{Li}_{1 \pm y} \mathrm{NiO}_{2}$ and a new $\mathrm{Li}_{2} \mathrm{NiO}_{2}$ phase with the $\mathrm{Ni}$ $(\mathrm{OH})_{2}$ structure. Solid State Ionics 1990, 44 (1-2), 87-97.

72. Chiang, Y.-M.; Wang, H.; Jang, Y.-I., Electrochemically Induced Cation Disorder and Phase Transformations in Lithium Intercalation Oxides. Chem. Mater. 2001, 13 (1), 53-63.

73. Zheng, S. J.; Fisher, C. A. J.; Hitosugi, T.; Kumatani, A.; Shiraki, S.; Ikuhara, Y. H.; Kuwabara, A.; Moriwake, H.; Oki, H.; Ikuhara, Y., Antiphase inversion domains in lithium cobaltite thin films deposited on single-crystal sapphire substrates. Acta Mater. 2013, 61 (20), 7671-7678.

74. Ulvestad, A.; Singer, A.; Clark, J. N.; Cho, H. M.; Kim, J. W.; Harder, R.; Maser, J.; Meng, Y. S.; Shpyrko, O. G., Topological defect dynamics in operando battery nanoparticles. Science 2015, 348 (6241), 1344-1347.

75. Fuggle, J. C.; Sawatzky, G.; Allen, J., Narrow-Band Phenomena-Influence of Electrons with Both Band and Localized Character. Plenum Press: 1988.

76. Mori, D.; Kobayashi, H.; Okumura, T.; Nitani, H.; Ogawa, M.; Inaguma, Y., XRD and XAFS study on structure and cation valence state of layered ruthenium oxide electrodes, $\mathrm{Li}_{2} \mathrm{RuO}_{3}$ and $\mathrm{Li}_{2} \mathrm{Mn}_{0.4} \mathrm{Ru}_{0.6} \mathrm{O}_{3}$, upon electrochemical cycling. Solid State Ionics 2016, 285, 66-74.

77. Wang, J. C.; Terzic, J.; Qi, T. F.; Ye, F.; Yuan, S. J.; Aswartham, S.; Streltsov, S. V.; Khomskii, D. I.; Kaul, R. K.; Cao, G., Lattice-tuned magnetism of $\mathrm{Ru}^{4+}\left(4 \mathrm{~d}^{4}\right)$ ions in single crystals of the layered honeycomb ruthenates $\mathrm{Li}_{2} \mathrm{RuO}_{3}$ and $\mathrm{Na}_{2} \mathrm{RuO}_{3}$. Phys. Rev. B 2014, 90 (16), 161110

78. Chen, S.; Wang, L.-W., Double-hole-induced oxygen dimerization in transition metal oxides. Phys. Rev. B 2014, 89 (1), 014109.

79. Kalathil, A. K.; Arunkumar, P.; Kim, D. H.; Lee, J.-W.; Im, W. B., Influence of $\mathrm{Ti}^{4+}$ on the Electrochemical Performance of Li-Rich Layered Oxides - High Power and Long Cycle Life of $\mathrm{Li}_{2} \mathrm{Ru}_{1-\mathrm{x}} \mathrm{Ti}_{\mathrm{x}} \mathrm{O}_{3}$ Cathodes. ACS Appl. Mater. Interfaces 2015, 7 (13), 7118-7128.

80. Sarkar, S.; Mahale, P.; Mitra, S., Lithium Rich Composition of $\mathrm{Li}_{2} \mathrm{RuO}_{3}$ and $\mathrm{Li}_{2} \mathrm{Ru}_{1-x} \mathrm{Ir}_{\mathrm{x}} \mathrm{O}_{3}$ Layered Materials as Li-Ion Battery Cathode. J. Electrochem. Soc. 2014, 161 (6), A934-A942.

81. Johnson, C. S.; Kim, J.-S.; Kropf, A. J.; Kahaian, A. J.; Vaughey, J. T.; Fransson, L. M. L.; Edström, K.; Thackeray, M. M., Structural Characterization of Layered $\mathrm{Li}_{\mathrm{x}} \mathrm{Ni}_{0.5} \mathrm{Mn}_{0.5} \mathrm{O}_{2}(0<\mathrm{x} \leq 2)$ Oxide Electrodes for Li Batteries. Chem. Mater. 2003, 15 (12), 2313-2322.

82. Liu, H.; Strobridge, F. C.; Borkiewicz, O. J.; Wiaderek, K. M.; Chapman, K. W.; Chupas, P. J.; Grey, C. P., Capturing metastable structures during high-rate cycling of $\mathrm{LiFePO}_{4}$ nanoparticle electrodes. Science 2014, 344 (6191), 1252817. 
ToC Graphic

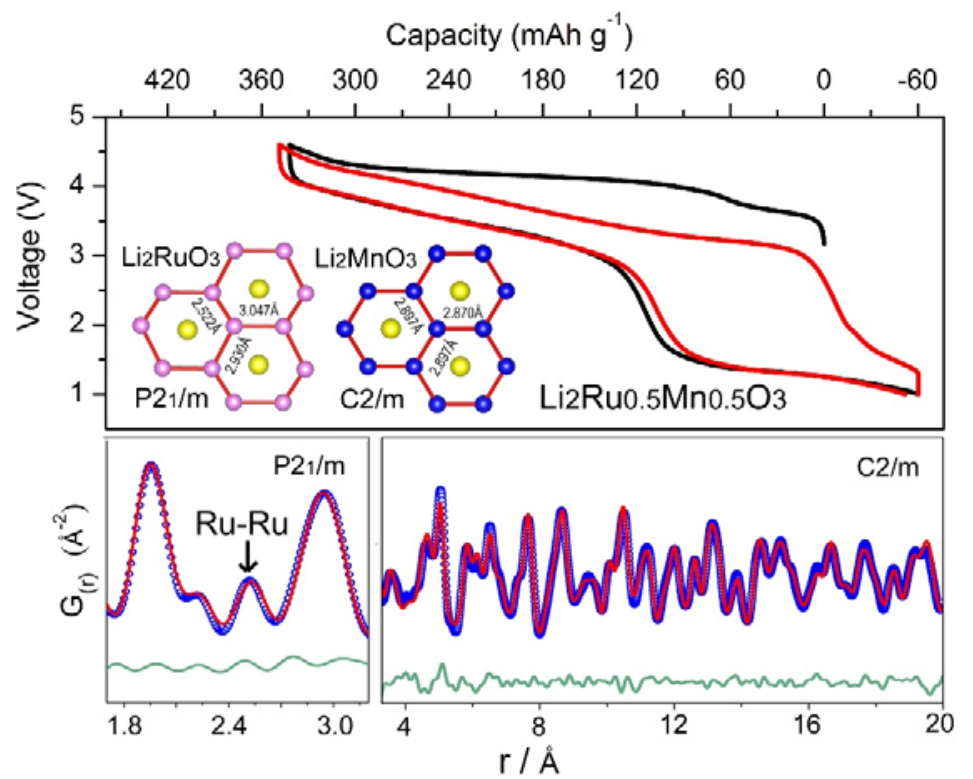

